Gümüş, N. / Journal of Yasar University, 2020, 15/58, 381-396

\title{
Z Kuşağı Tüketicilerin Satın Alma Karar Tarzlarının İncelenmesi
}

\section{Investigation of Generation Z Consumers' Purchasing Decision Making Styles}

\author{
Niyazi GÜMÜŞ, Bolu Abant İzzet Baysal Üniversitesi, Türkiye, niyazigumus@ibu.edu.tr \\ Orcid No: 0000-0001-8737-3114
}

\begin{abstract}
Öz: Aynı zaman diliminde dünyaya gelmiş ve bundan dolayı hayatı yorumlayış biçimleri, sahip oldukları değerler ve tüketim alışkanlıkları birbirine benzer olan nesiller markaların ve firmaların her daim hedefinde olmuştur. Şimdiye kadarki kuşaklardan ayrı olarak bilgi ve iletişim teknolojilerindeki gelişmelerin içine doğan Z kuşağı çok yakında kendi gelirini elde edecek ve tüketim davranışlarında bulunacaktır. Dolayısı ile bu kuşağın alışveriş alışkanlıklarının ve satın alma karar tarzlarının incelenmesi marka ve firmalar açısından büyük önem taşımaktadır. Bu araş̧ırmanın amacı Z kuşağı tüketicilerin satın alma karar tarzlarınin incelenmesi olarak belirlenmiştir. Bu kapsamda Kastamonu'da Ocak-Şubat 2019 tarihleri arasında kolayda örnekleme yöntemi ile belirlenen 320 ögrenciye anket uygulanmıștır. Araștırma sonucunda Z kușağının satın alma kararlarında sosyal medya ünlülerinin etkisi açıkça görülürken, kalite ve fiyat bu kuşağın satın alım kararlarını etkileyen en önemli unsurlar olarak öne çıkmıştır.
\end{abstract}

\section{Anahtar Sözcükler: Z Kuşağı, Satın Alma Karar Tarzları, Tüketici Davranışları JEL Sinfflandirmasl: M30, M31, M39}

\begin{abstract}
Generations that have been born in the same time period, and therefore, have common perceptions, values and consumption habits have always attracted the attention of brands and companies. Different from the generations to date, Generation Z, who is born into advances in information and communication technologies, will soon be financially independent and develop consumption behaviors. It is, therefore, critical for brands and companies to determine its consumption habits and purchase decisions. The aim of this study was, therefore, to investigate the purchase decisions of Generation Z consumers. This study was conducted between January and February 2019 in Kastamonu. The study sample consisted of 320 students recruited using convenience sampling. Data were collected using a questionnaire. Results showed that social media celebrities have a significant effect on the purchase decisions of Generation $Z$ consumers and that quality and price are the most important factors affecting their purchase decisions.
\end{abstract}

Keywords: Generation Z, Purchasing Decision Styles, Consumer Behavior

JEL Classification: M30, M31, M39

\section{Giriş}

İnsanoğlu yeryüzüne adımını attıktan bu yana zaman içinde yaşam tarzı, ihtiyaçları, tüketim biçimleri, karar verme tarzları bağlamında çok önemli değişimler yaşamıştır. Ancak kabul edilmektedir ki son yirmi yılda bu değişim çok daha hızlı gerçekleşmiştir. Bilgi ve iletişim teknolojilerinde meydana gelen gelişmelerin baş döndürücü hızı karşımıza yepyeni kavramlar, yepyeni mal ve hizmetler çıkarmıştır. Sosyal medya, yapay zekâ, robot teknolojileri vb. gelişmeler örnek olarak verilebilir. Z kuşağı olarak ifade edilen bireylerin içe doğdukları hızlı değişimin bu bireylerin, tüketim alışkanlıklarına, karar verme biçimlerine ve değer yargılarına etki etmemesi beklenemez. Teknoloji, sosyoloji vb. alanlarda ortaya çıkan gelişme ve olaylar dikkate alındığında 2000 ve sonrasında dünyaya gelen bireylerin yaşamında daha önceki nesillerde görülmeyen bir yoğunluğun yaşandığı görülmektedir. Yaşanılan tüm bu gelişmeler şüphesiz bir tüketici olarak bu neslin öncelik sıralamasında, karar alma biçimlerinde çok önemli değişikliklere neden olduğu düşünülmektedir. 2000 ve sonrası dünyaya gelenleri ifade eden Z kuşağı (Williams, 2010) üyelerinden eğitim hayatına devam edenler bugün, üniversite 1 ya da 2 . Sınıfta öğrenimlerine devam etmektedirler. Çalışma hayatına atılanlar ise kendi gelirlerini kazanmaya başlamışlardır. Sahip oldukları teknolojik bilgi nedeniyle gerek kendi satın alma kararlarını gerekse aileleri başta olmak üzere çevrelerindeki tüketicilerin kararlarını etkileme güçleri $Z$ kuşağı bireylerin daha iyi anlaşılmasına ve araştırılmasına yönelik çalışmaların sayısında büyük bir artışa neden olmuştur. Teknolojik cihazların içine doğmaları nedeniyle teknoloji ürünleri başta olmak üzere çok sayıda marka için hedef pazar olarak görülen bu tüketici grubuna gösterilen ilginin giderek artacağı düşünülmektedir. Ayrıca bu kuşak üyelerinden çalışma hayatında bulunanların kendi gelirlerini kazanmaları ve kendi tüketim kararlarını vermeleri nedeniyle çok çeşitli marka ve firmanın hedef pazarında yerini aldıkları düşünülmektedir. Sonuç olarak gerek mevcut durumdaki ekonomik güçleri gerekse gelecekteki büyük pazar potansiyelleri nedeniyle $\mathrm{Z}$ kuşağına mensup tüketiciler bu araştırmada olduğu gibi çok daha fazla araştırmaya konu olmaya devam edeceklerdir.

Marka ve firmalar Baby Boomers, X, Y olarak ifade edilen önceki kuşaklardan daha farklı özelliklere sahip olduğu düşünülen $Z$ kuşağına hangi pazarlama stratejileri ile ulaşılacağı konusunda yoğun bir çaba sarf etmektedirler. Çünkü hiçbir kalıba girmeyen bu kuşağa ulaşmanın sanıldığı kadar kolay olmayacağını fark etmiş durumdadırlar. Önemli bir kısmının eğitim hayatına devam ettiği düşünüldüğünde kendi gelirini elde etmemiş olmalarına rağmen üzerinde çok fazla 
araştırmanın yapılmış ve yapılıyor olması bunun en önemli göstergesidir. Araştırmacılar tarafından ülkemizde de son yıllarda bu nesli daha iyi tanımak adına farklı disiplinlerde yapılan çalışmalarda önemli bir artış gözlenmektedir.

$\mathrm{Bu}$ kapsamda bu araştırmanın amacı Z kuşağı tüketicilerin satın alma karar tarzlarının incelenmesi olarak belirlenmiştir. Bu kapsamda öncelikle karar verme tarzları kavramı, Z kuşağı ve genel özellikleri ele alınmıştır. Son olarak ise $Z$ kuşağı tüketicilerin satın alma karar tarzlarını ortaya koyabilmek adına yapılan araştırma bulguları ele alınmıştır. Araştırmanın başta bu alanda çalışan araştırmacılar olmak üzere $\mathrm{Z}$ kuşağı tüketicileri hedef pazar olarak belirleyen marka ve firmaların pazarlama stratejilerinde yardımcı olacak ipuçları sağlaması açısından önemli olacağı düşünülmektedir.

\section{Tüketicilerin Karar Verme Tarzları}

Tüketici davranışı, kişinin ürün ve hizmetleri seçme, satın alma, kullanma ve elden çıkarmadaki kararları ve bunlarla ilgili faaliyetleri olarak tanımlanabilir. İfadeden de anlaşılacağı üzere, tüketici davranışlarının temelini satın alma karar süreci oluşturmaktadır (Erciş vd., 2007:282). Her bireyin temel sosyal değerleri ve tüketim alışkanlıkları bireylerin büyüme dönemlerinde onları çevreleyen değerlerin etkisiyle oluşmaktadır (Seçkin, 2000). Bundan dolayı kişilerin sahip olduğu alışkanlıklar değerlendirilirken içinde yetiştikleri dönemin sosyal, politik, kültürel ve ekonomik koşulları dikkate alınmalıdır. Kaldı ki bu sayılan faktörlerin sadece ulusal etkisinin yanı sıra iletişim teknolojilerinde meydana gelen gelişmeler nedeniyle uluslararası alandaki gelişmeler de bireylerin alışkanlıkları üzerinde son derece etkili olabilmektedir (Torlak, 2016:138). Artan rekabet koşulları nedeniyle marka ve firmalar neredeyse tüm enerjilerini tüketicilerin davranışlarını anlamaya yöneltmiş durumdadır. Bu doğrultuda pazarlama ve tüketici davranışları literatüründe uzun zamandır devam eden tüketici sınıflandırma çalışmaları, tüketicileri neden ve nasıl satın aldıkları temeline göre belirli sayıda sınıfa ve tipe ayrıştırmayı, böylece benzer beklenti ve davranışı gösteren bu gruplara uygulanacak pazarlama stratejilerinin belirlenmesinde yöneticilere yardım etmeyi hedeflemektedir (Dursun vd., 2013:294). Tüketicilerin günümüzde ihtiyaçlarını karşılayabilmelerini sağlayacak alternatiflerin arttığı, yaşam tarzlarının önemli ölçüde farklılaştı̆̆ ve geçmişe oranla daha bilgili ve bilinçli hale geldikleri bilinmektedir. Bu nedenle rekabet avantajı elde etmek isteyen marka ve firmaların tüketicilerin nasıl satın alma kararı verdikleri, hangi faktörlerin satın alma davranışı üzerinde etkili olduğuna dair detaylı analizler yapmaları gerekmektedir (Yeniçeri ve Özal, 2016:136).

Konuyla ilgili olarak yoğun biçimde araştırılan konuların başında tüketicilerin karar verme tarzları gelmektedir. Tüketici karar verme tarzları ile ilgili yapılan literatür incelemesinde tüketicilerin satın alma tarzlarını belirleyebilmek için üç yolun önerildiği görülmektedir: psikografik/yaşam tarzı yaklaşımı, tüketici tipolojisi yaklaşımı ve tüketici özellikleri yaklaşımı (Lastovicka,1982; Sproles ve Kendall 1986). Tüketici tipolojisi yaklaşımı, tüketicileri belirli ürün grupları olarak sınıflandırırken, tüketici özellikleri yaklaşımı, tüketici karar verme tarzlarını etkileyen bilişsel ve duyusal boyutların (rasyonel ve kalite bilincinden dürtüsellik ve aşırı bilgi yüklemesine kadar) altını çizmektedir (Leo vd., 2005). Tüketici karakteristik yaklaşımı, tüketicilerin bilişsel ve duyuşsal eğilimlerini hedef alan, tüketici karar özelliklerini ölçmek için açıklayıcı ve güçlü yapılar sunmaktadır (Kamaruddin ve Mokhlis, 2003). Tüketici özellikleri yaklaşımı, karar vermede tüketicilerin zihinsel yönelimlerine odaklanmakta ve bu nedenle tüketici araştırmalarında en güçlü yaklaşım olarak öne çıkmaktadır. Bu yaklaşım, tüketicilerin alışveriş ve satın alma yönündeki genel yönelimini tanımlamakta ve bu karar verme tarzlarını belirlemede yardımcı olmaktadır (Tanksale vd., 2014).

Tüketicilerin karar verme tarzları ile ilgili yapılan sınıflandırmalardan bir diğeri ise (Scott ve Bruce, 1995) tarafindan yapılan sınıflandırmadır ve rasyonel, sezgisel, bağıml, çekingen ve kendiliğinden oluşan karar verme tarzı olmak üzere beş faktörden oluşmaktadır. Bunlardan ilki, rasyonel stil, alternatiflerin araştırılması ve mantıklı değerlendirilmesi ile karakterize edilmektedir. Sezgisel stil, ayrıntılara ve ön sezilere verilen önem ile karakterize edilmektedir. Bağımlı karar verme, başkalarının tavsiyelerine güvenerek araştırma yapmakla karakterize edilirken kaçınma yönlü karar verme tarzı ise, mümkün olduğunca karar vermekten kaçınma ile karakterize edilmektedir. Son olarak kararların anlık kendiliğinden alınması tarzı ise karar verme sürecinin en kısa sürede tamamlama arzusuyla karakterize edilmektedir (Scott ve Bruce, 1995).

Tüketici karar verme tarzları tüketicilerin alışverişe yönelik tutumlarını ve davranışlarını etkilemektedir. Tüketici karar verme stilleri farklı ürünler, hizmetler satın alırken tüketicilerin uyduğu temel satın alma kararlarını ifade etmektedir (Tanksale vd., 2014). Tüketiciler, satın alma karar süreci içerisinde ulaşılabilirlik, memnuniyet, kalite, hizmet, müşteri ilişkileri vb. özelliklere önem vermektedirler (Onurlubaş ve Altunışık, 2019).

Tüketicilerin karar verme tarzları ile ilgili kapsamlı araştırmalardan biri Sproles ve Kendall (1986) tarafindan gerçekleştirilmiştir. Sproles (1985) tüketici karar alma tarzlarını analiz etmek ve kavramsal bir çerçeve oluşturmak amacıyla tüketici karar verme yaklaşımının temelini oluşturarak ilk etapta elli maddelik bir ölçek geliştirmiştir. Sproles çalışmasında kişilerin satın alma ve genel olarak alışveriş eğilimlerini ölçmeye yönelik bir çalışma yapmıştır. Çalışma sonucunda dokuz farklı karar verme tarzı ortaya çıkmıştır. Bunlar (1) Moda bilinci, (2) Fiyat duyarlılığı, (3) Yüksek kalite, 
(4) Sosyal olarak bilinçlilik, (5) Mükemmelliyetçilik, (6) Memnun, (7) Alışveriş bilinçliliği, (8) Hedonist alışveriş, (9) Planlı müşteri boyutlarıdır. Daha sonra yapılan faktör analizinde dokuz boyuttan altı tanesi doğrulanmıştır. Sonrasında ise bu çalışma Sproles ve Kendall (1986) tarafından geliştirilmiş olup kırk bir madde ve sekiz farklı boyuttan oluşan tüketici karar verme tarzı olarak isimlendirilmiştir. Sproles ve Kendall (1986)'a göre tüketici karar verme tarzları arasından duygusal ve bilişsel özellikleri kapsayan en temel sekiz zihinsel özellik: (1) mükemmeliyetçilik veya yüksek kalite odaklılık; (2) marka odaklılık; (3) yenilik-moda odaklılık; (4) eğlence, hedonist odaklılık; (5) fiyat odaklılık; (6) düşünmeden alışveriş etme/dikkatsizlik/plansız alışveriş; (7) çeşit karmaşası yaşama ve (8) alışkanlık, marka bağlılı̆ı odaklılık olarak ortaya çıkmıştır.

1. Mükemmeliyetçi-Yüksek Kalite Odaklılık: Yaptıkları alışverişlerde satın aldıkları ürünlerde en iyi kaliteyi dikkatlice ve sistematik olarak arayan tüketicileri ifade etmektedir.

2. Marka Odaklılık: Marka ve kalite bilincine sahip tüketicilerdir. Fiyat = Kalite anlayışını savunan bu tüketiciler, iyi bilinen ve en pahalı ürünleri, markaları satın alma eğilimi göstermektedirler.

3. Yenilik-Moda Odaklılık: Bu faktör, yeni mal ve hizmetleri bulmayı seven, modayı takip eden ve ona uygun alışveriş yapan tüketicileri ifade etmektedir.

4. Eğlence-Hedonist Odaklılık: Bu faktör, alışverişi keyifli bulan, eğlence için alışveriş yapan tüketicileri ifade etmektedir.

5. Fiyat Odaklılık: Bu faktör, indirim zamanını bekleyen, ödediği fiyatın karşılığını arayan ve düşük fiyata duyarlı olan tüketicileri ifade etmektedir.

6. Düşünmeden Alışveriş Etme/Dikkatsizlik/Plansız Alışveriş: Bu faktör, plansız alışveriş yapan, yaptıkları harcamayı çok fazla düşünmeyen tüketicileri ifade etmektedir.

7. Çeşit Karmaşası Yaşama: Bu faktör, çok fazla marka, mal ve hizmet olduğu için kafasının karıştı̆ı̆ıı düşünen ve seçim yapmakta zorlanan tüketicileri ifade etmektedir.

8. Alışkanlık-Marka Bağlılığı Odaklılık: Bu faktör, sevdiği belirli marka ve mağazaları olan ve bu marka ve mağazalardan satın almayı tercih eden tüketicileri ifade etmektedir.

\section{Tüketici Karar Verme Tarzlarında Yaș Faktörü}

Tüketicilerin satın alım kararlarında etkili olan demografik özelliklerden biri de yaş faktörüdür (Kotler, 2000). İnsanın yaşı ilerledikçe değerleri, hayat biçimi ve bu ölçüde tüketim tutum ve alışkanlıkları da değişmektedir. Beş yaşındaki bir insanla yirmi yaşındaki bir insanın ya da altmış yaşındaki bir insanın gereksinimleri birbirinden önemli ölçüde farklılıklar göstermektedir. Bununla birlikte aynı yaş grupları altındaki insanlar benzer değerler, gereksinimler ve davranış biçimlerine sahip olmaktadırlar. Yani aynı dönemlerde doğmuş kişiler o dönemin kültürel yapısına göre benzer özellikler taşımaktadırlar. Bu nedenle marka ve firmalar, bir pazarlama planı geliştirirken yaş gruplarını mutlaka dikkate alırlar (Tekvar, 2016). Yaş boyutunun tüketici davranışlarında farklı̆̆g neden olduğu ile ilgili literatürde çok sayıda çalışma bulunmaktadır. Örneğin Altuntuğ (2012), çalışmasında geleceğin tüketicisinin standart bir kimliğin ötesinde, her duruma uygun kimlikler taşıyacağını BB'ların, $\mathrm{X}^{\prime}$ lerin $\mathrm{Y}^{\prime}$ lerin her birinden çeşitli özellikler taşıyacak olan geleceğin tüketicilerinde, $Z$ kuşağının özelliklerinin daha baskın olduğu puzzle bir profil oluşturacağını belirtmiştir. Adıgüzel vd. (2014) farklı tüketici kuşaklarının hem karakter, hem çalışma yaşamları hem de sosyal hayatlarında önemli farklılıklar olduğunu belirtmişlerdir. Erdem (2016) yaptığı araştırmada tüketicilerin yaşları arasında marka bağl1lıkları, mükemmeliyetçilikleri ve alışveriş yapmaya yönelik tutumları açısından farklılıklar olduğunu ortaya koymuştur. Benzer şekilde Bilgili (2016) X ve Y kuşaklarından oluşan katılımcılarla yaptığı araştırma sonucunda, $\mathrm{X}$ ve $\mathrm{Y}$ kuşağına mensup tüketicilerin karar verme tarzları arasında anlamlı bir fark olduğunu tespit etmiştir. Konuyla ilgili olarak Yücel (2017) yapmış olduğu çalışmasında ise karar verme tarzları olan "çeşit karmaşası yaşayan tüketici" haricindeki mükemmeliyetçilik ve yüksek kalite odaklılık, marka bilinci, eğlence-haz odaklılık ve düşünmeden alışveriş yapma boyutları açısından katılımcıların demografik özelliklerinden biri olan yaş değişkenine göre farklılaştığını ortaya koymuştur. Sarı ve Harta (2018) ise yaptıkları araştırmada sessiz kuşak, bebek patlaması kuşağı, X, Y ve Z kuşaklarını karşılaştırmışlardır. Karşılaştırma sonucunda tüketici kuşaklarının aylık olarak alışveriş için ayırdıkları bütçe ve yaşları arasında anlamlı bir farklılık olduğu, yaş arttıkça alışveriş için ayrılan bütçenin de artmış olduğu tespit edilmiştir. Araştırmada bir ürünü en çok kendi beğenisiyle satın alan kuşağın $Z$ kuşağı olduğu, yaş arttıkça gıda harcamaları artarken, giyim harcamalarının azalmakta olduğu ortaya çıkmıştır. $Z$ kuşağının gıda harcaması yapmadığı, sağlık harcaması yapan tek kuşağın ise sessiz kuşak olduğu araştırmada ulaşılan bir diğer sonuç olmuştur. Benzer şekilde Deniz (2019) araştırmasında da tüketicilerin yaşları arasında karar verme tarzları açısından farklılıklar olduğunu ortaya koymuştur. Hızlan (2019) ise tüketicilerin çevrimiçi alışveriş boyutları olan, müşteri memnuniyeti ve müşteri güveni, e-sadakat, arama, kulaktan kulağa iletişim ve daha fazla ödeme istekliliği, güvenilirlik, doğruluk, erişim, navigasyon kolaylığı, 
güvence, kişiselleştirme, fiyat bilgisi ve site estetiği gibi konularda da yaşları arasında istatistiksel olarak anlamlı farkl1lıklar olduğunu ortaya koymuştur.

\section{Z Kuşağı ve Özellikleri}

Türk Dil Kurumu Felsefe Terimleri Sözlüğü, kuşak kavramını, aşağı yukarı benzer yıllarda doğmuş olup aynı çağın koşullarını sahip olan, dolayısıyla birbirine benzer sıkıntıları, yazgıları yaşamış, benzer ödevlerle yükümlü olmuş kişiler topluluğu olarak tanımlamaktadır. Marka ve firmalar açısından bakıldığında ise aynı kuşak üyelerinin benzer istek ve ihtiyaçlara, benzer tüketim kalıplarına ve benzer karar verme tarzlarına sahip oldukları düşünülmektedir. Şüphesiz bu benzerlikler bu kuşağı hedef pazar olarak belirleyen marka ve firmalar açısından büyük kolaylıklar sağlamaktadır. Çünkü pazarlama stratejileri belirlerken hedef kitlenin tüketim alışkanlıklarını anlamak ve çeşitli öngörülerde bulunabilmek için bireyleri ait olduğu kuşağın özeliklerine göre değerlendirmek daha gerçekçi sonuçlara ulaşılmasını sağlamaktadır.

Kuşakların belirlenmesinde araştırmacılar tarafından en sık başvurulan yöntem doğum tarihleridir. Örneğim 19461964 arasında doğanlar Baby Boomerlar olarak, 1965-1979 arasında doğanlar X kuşağı, 1980-1998 arasında doğanlar Y kuşağı ve 1995-2009 arasında dünyaya gelenler ise Z kuşağı olarak isimlendirilmektedirler (Goh ve Lee, 2018). Başka bir çalışmada ise 1995-2012 yılı arasında doğanlar Z kuşağı olarak ifade edilmektedir (Kitchen ve Proctor, 2015). Benzer şekilde Tablo 1'de de görüldüğü gibi 2000 ve sonrasında doğanları Z kuşağı olarak tanımlayan çalışmalar da bulunmaktadır. Bu sınıflandırmalara ek olarak literatürde birbirinden farklı sınıflandırmalar bulunmaktadır. Bu sınıflandırmalardan birkaçı Tablo 1'de yer almaktadır (Hatipolu, 2014).

Tablo 1. Kuşakların Sınıflandırılması

\begin{tabular}{|c|c|c|c|}
\hline Yazarlar & X Kuşağı & Y Kuşağı & Z Kuşağı \\
\hline Appelbaum (2005) & 1961-1981 & & \\
\hline Broadbridge (2007) & & 1977-1994 & \\
\hline $\begin{array}{l}\text { Cennamo ve } \\
\text { Gardner (2008) }\end{array}$ & 1962-1979 & 1980 ve sonras 1 & \\
\hline Hammill (2005) & $1965-1980$ & $1981-2000$ & 2001 ve sonras1 \\
\hline Chen ve Choi (2008) & 1965-1977 & 1978 ve sonras 1 & \\
\hline Gürsoy (2008) & 1961-1980 & $1981-2000$ & \\
\hline Kuran (2010) & & & $2000-2020$ \\
\hline Jurkiewicz (2000) & 1963-1981 & & \\
\hline $\begin{array}{l}\text { Jurkiewicz ve Brown } \\
\text { (1998) }\end{array}$ & 1961-1981 & & \\
\hline Oblinger (2005) & & & 2000 ve sonras 1 \\
\hline $\begin{array}{l}\text { Lamm ve Meeks } \\
\text { (2009) }\end{array}$ & 1961-1980 & $1981-2000$ & \\
\hline Lyons (2007) & $1965-1979$ & 1980 ve sonras1 & \\
\hline $\begin{array}{ll} & \text { Sessa } \\
(2007) & \\
\end{array}$ & 1964-1982 & 1983 ve sonras 1 & \\
\hline $\begin{array}{l}\text { Smola ve Sutton } \\
(2002)\end{array}$ & $1965-1977$ & & \\
\hline Wong (2008) & $1965-1981$ & $1982-2000$ & \\
\hline $\begin{array}{l}\text { Williams ve Page } \\
\text { (2011) }\end{array}$ & $1965-1976$ & 1977-1994 & 1994 ve sonras1 \\
\hline $\begin{array}{l}\text { Howe ve Strauss } \\
(2000)\end{array}$ & 1961-1981 & $1982-2000$ & \\
\hline
\end{tabular}

2020 yılına kadar tüm tüketicilerin yaklaşık yüzde 40'ını oluşturması beklenen (Perlstein, 2017) Z Jenerasyonu, içine doğdukları global teknolojik köyde dünyanın herhangi bir noktasındaki bir kişiyle saniyeler içinde haberleşebilmektedir. Günün her saati internette bilgi paylaşımına yatkın olan bu nesil, sosyalliği de bu ortamlara kaydırarak, farklı bir iletişsim şekli benimsemektedir. Hızlı ve kolay iletişim biçimleri, paylaşım imkânlarında artışs sağlayarak olumlu katkılar sağlasa da sosyal medyanın karanlık yüzü ve yol açtığı bağımlılık konusunda da pek çok çalışma yapılmıştır. Özellikle, internet bazlı oyunların olumsuz etkileri, Z kuşağı üzerinde hissedilmektedir (Sarığlu ve Özgen, 2017:245). I-Generation, 
Internet kuşağı, Bir sonraki kuşak ve Ağ kuşağı da Z kuşağını tanımlamak için kullanılan diğer ifadelerdir (Levickaité, 2010:173). Önceki kuşakların aksine sosyal medyanın içine doğmuş olan $Z$ kuşağı sosyal medya kanallarını daha çok iletişimini sürdürmek, araştırma yapmak ve eğlence amaçlı kullanmaktadır. $Z$ kuşağı sosyal medyayı eğlencenin yanı sıra ürün ve hizmetler hakkında bilgi edinme, fiyat araştırma, ilişkilerini sürdürme ve iş birliği yapma gibi konularda yoğun biçimde kullanmaktadır (Hidvegi ve Kelemen-Erdös, 2016:175; Sarığlu ve Özgen, 2018:1080). Z kuşağını, cep telefonları, kablosuz internet ve interaktif bilgisayar oyunları aracıllğ̆ ile geniş çapta dijital iletişim teknolojilerine kendi evlerinde erişen ilk nesil olarak tanımlamak yanlış olmayacaktır (Bassiouni ve Hackley, 2014). Dijital yerliler olarak da tanımlanan Z kuşağı insanlık tarihinin el, göz, kulak vb. motor becerileri senkronizasyonu en yüksek nesli olarak sonuç odakl1, tatminsiz, kararsız ve doğuştan tüketici olarak görülmektedir (Taş vd., 2017:1037). Z Kuşağı tüketicilerin günlük yaşamlarının büyük bölümünü internetin, tabletlerin ve akıllı telefonların kapladığını düşündügüumüzde $Z$ kuşağı için internetsiz ya da teknolojisiz bir tüketim davranışını tarif etmek de kolay olmayacaktır (Bayrakdaroğlu ve Özbek, 2018:10). Z kuşağı bireyler, ayrıca ailelerinin tüketim kararlarında çok etkili olmaları nedeniyle, pazarlamacıların özel önem verdiği bir kuşaktır. $Z$ kuşağı bireyler, her konuda kişiselleşmiş, kendine özgü ve imaja dayanan bir tüketime yönelerek, adeta pür tüketici olarak nitelenebilecek bir profil çizmektedirler. Eğitim ve ekonomik açıdan diğer kuşaklara göre daha donanımlı olan $Z$ kuşağı bireyler, istediği her ürünü hemen almak, hemen tüketmek ve sonrasında yeni tüketim deneyimlerine yönelmek istemektedirler (Altuntuğ, 2012:209).

Z kuşağı bireyler dijital teknoloji ile en fazla ilişkisi olan kuşak olarak öne çıkmaktadır. Online alışverişlerde fiyat ve lüks duyarlılıklarının tamamına karşılık gelen çok sayıda alternatifin ulaşılabilir hale gelmesi ve $Z$ kuşağının da bunun farkında olarak aile fertlerini etkileyebilmesi mümkün olmaktadır. Dolayısı ile kendi gelirleri olmamasına rağmen tüketim faaliyetlerinde bu kuşağın belirleyici olma özelliği öne çıkmaktadır. Kısa süre sonra kendi gelirlerine sahip olacak olan bu kuşak pazarlama uzmanlarının marka ve firmaların dikkatlerini yoğun biçimde çekmektedir. Zira çok kısa bir gelecekte bu kuşak tüketimde belirleyici konumunu daha da güçlendirecek ve fiziki alışveriş mekânlarında daha da fazla söz sahibi olacaktır (Torlak, 2016:138; Budac, 2014:9). Bununla birlikte, 2019 yılı itibariyle en erken 1995 yılında doğan Z kuşağı bireylerden çalışma hayatını tercih edenlerin olabileceği, bunun yanı sıra eğitim ve çalışma hayatını birlikte sürdürenlerin de olabileceği unutulmamalıdır. Bu nedenle $\mathrm{Z}$ kuşağı bireylerin birer tüketici olarak ekonomik hayatta varlık göstermeye başlamış olabileceklerinden söz edilebilecektir.

Z kuşağı mal ve hizmetlerin tüketimi ile ilgili bilgilere erişmek, satın alma alternatifleri aramak veya satın alımlar yapmak ve arkadaşlarla etkileşim kurmak için çoğunlukla mobil cihazlar kullanmaktadır. Sosyal ağ kullanımının mobil hale gelmesi ile oluşan mekân ve zaman bağımsızlığı, akıllı telefon kullanımı üzerinde bir bağımlılık yaratmıştır (Işık ve Kaptangil, 2018: 696). Dolayısı ile bu kuşağın üyelerini hedefleyen marka ve firmaların mobil ve sosyal medyayı birbirine entegre edecek stratejiler geliştirmesi gerekmektedir (Budac, 2014:9). Z kuşağı üyeleri müşteri olarak memnun kalmadıkları bir ürün hakkındaki düşüncelerini sosyal medya aracılığıyla dile getirmektedirler. Bu bireyler birer tüketici olarak beklentilerini ifade ederlerken, aynı zamanda satın aldıkları ürünleri kendilerine özgü bir biçimde yeniden şekillendirmektedirler. Dolayısıyla tüketimi, yalnızca satın alma olarak görmedikleri, sorguladıkları ve alternatifler oluşturdukları görülmektedir. Z kuşağı üretim-tüketim olgusuna, yaratıcılığa ve bilinçli satın almaya önceki kuşaklara göre daha fazla önem veren bir kuşak olarak karşımıza çıkmaktadır (Duygulu, 2018:642).

Sosyal medyayı aktif biçimde kullanan gençler markaların sosyal medyada yer almasına ve dijital araçlar ile alışveriş yapma imkânının sunulmasına büyük önem vermektedirler. Bu kuşağın üyeleri satın aldıkları ürünlerin ve yaşadıkları deneyimlerin olabildiğince benzersiz olmasını beklemektedirler (Baldwin, 2018). Değer kavramına çok önem veren Z kuşağı dürüst ve şeffaf olmayan markaları sosyal medyada şiddetle eleştirmektedir. Markaların bu neslin gençleriyle iyi bir bağlantı için, bu kuşağın bireylerinin eşsiz zevkleri hakkında derinlemesine bilgi sahibi olmaları gereklidir. Teknoloji kullanımı konusunda son derece yetkin olan bu neslin üyelerine karşı markaların alışveriş sürecinde elde ettiği verilerin gizliliği konusunda çok daha dikkatli olmaları gerekmektedir. Ayrıca, ürünlerin ve markaların çevresel etkilerini ve karbon ayak izini dikkate alan $\mathrm{Z}$ kuşağını hedefleyen marka ve firmaların yeşil ürünler sunmayı ve çevreye yönelik proaktif bir tutum sergilemeyi düşünmeleri gerekmektedir (Budac, 2014:10; Bulut vd., 2017:602; Karaca, 2013). Sahip olduğu özellikler nedeniyle markalar için ulaşılması zor görülen $Z$ kuşağı, vizyon sahibi markalar için artan bir satın alma gücüne sahip, herhangi bir markaya sadık olmayan büyük bir tüketici pazarını ifade etmektedir (Budac, 2014:10 ). Bu kuşağa bağlanmak için, markaların tüm pazarlama karması elemanlarını yeniden tanımlamaları gerekmektedir. Eski marka pazarlaması kuralları artık bu genç hedef kitle için geçerli değildir. Çünkü bu kuşak üyelerinin markaya olan sadakatleri daha düşüktür. Örneğin, Z kuşağına mensup pazarlama kampanyalarına ilgisiz olan bir bireyin sosyal medya yoluyla arkadaşı tarafından önerilen bir ürünü satın alması çok daha muhtemel olmaktadır (Budac, 2014:12; Perlstein, 2017). Önceki kuşaklara göre çok fazla seçeneğe sahip olan Satın alma kararlarında estetik ve tasarım temelli yenilikler, satın alınacak ürünlerin yaşamı kolaylaştırması, alışveriş esnasında sunulan kişisel bilgilerin gizliliğine verilen önem ve bu ürünlerin bireyi gerçek hayattan uzaklaştırması Z kuşağının tüketici özellikleri olarak ifade edilmektedir (Wood, 
2013:1) Z kuşağ gerçek hayatta mahremiyetini ne kadar paylaşıyorsa, sosyal ağlarda mahremiyetini o düzeyde paylaşmaktadır (Çaycı ve Karagülle, 2014: 95).

$\mathrm{Z}$ kuşağı alışveriş öncesi bilgi ihtiyacının \%82,1 oranında internet, \%60 oranında aile ve arkadaş görüşleri, \%15,6 oranında ürün katalogları, $\% 11,3$ oranında broşürler ve $\% 6,7$ oranında ise satış elemanlarından sağlamaktadırlar (Hidvegi ve Kelemen-Erdös, 2016:179). Z kuşağının karar vermesini akran etkileşiminin olumlu etkilediği (Cruz, 2016; Silva vd., 2017) yapılan çalışmalarda ortaya konulmuştur. Yoğun biçimde sosyal medya kullanıcısı olan Z kuşağı ile ilgili İsveç'de yapılan bir araştırmada özellikle bu kuşağın bayan temsilcilerinin sosyal medya ünlülerini sıklıkla takip ettikleri tespit edilmiştir (Lea vd., 2018:2). Z kuşağının satın alım kararlarında en önemli faktörler olarak, kişisel deneyim, kalite ve fiyat ortaya çıkmıştır (Hidvegi ve Kelemen-Erdös, 2016:179). Z kuşağının satın alma kararları ile ilgili yapılan başka bir araştırmada da Z kuşağı üyelerinin ürünlerin kalitesi ve fiyatlarına özel bir hassasiyet gösterdiği, alışveriş yapmaktan kadınların erkeklerden daha çok zevk aldığı belirlenmiştir (Smalej, 2017:334). Türkiye'de Z kuşağı üzerine yapılan bir araştırmada ise katılımcıların açık ara ile en fazla Instagram ve ardından Facebook kullandığı tespit edilmiştir. Kullanım nedenleri arasında ise sohbet ve eğlence ilk iki sırada yer almıştır (Kılıç ve Karadayılı, 2017:301). Z kuşağı, arkadaşlarla aile arasındaki bağı güçlendirmek için sosyal medya ve diğer uygulamaları yoğun biçimde kullanmaktadır. Twitter, Instagram ve diğer sosyal medya uygulamaları $\mathrm{Z}$ kuşağı üyeleri arasında oldukça popüler olduğunu söylemek yanlış olmayacaktır.

Tablo 2. Türkiye Z Kuşağı Nüfus Projeksiyonu

\begin{tabular}{|c|c|c|c|}
\hline $\begin{array}{c}\text { Z Grubu Yaş } \\
\text { Aralıkları }\end{array}$ & 2018 & 2023 & 2040 \\
\hline $15-19$ & 6402806 & 6366376 & 6729892 \\
\hline $20-24$ & 6523846 & 6456912 & 6674359 \\
\hline
\end{tabular}

Kaynak: http://tuik.gov.tr/UstMenu.do?metod=temelist (21.05.2019)

Tablo 2'de 1995 ile 2000 yılı sonrasında dünyaya gelen Türkiye'nin Z kuşağı nüfus projeksiyonuna dair sayılar görülmektedir. Toplamda yaklaşı 13 milyonluk bir kitleyi oluşturduğu görülen Z kuşağı bireylerinin hali hazırda Türkiye nüfusu 82 milyon olarak düşünüldüğünde toplam nüfusun yaklaşık \%10'nu oluşturduğu anlaşılmaktadır. 2019 y1lı itibariyle $\mathrm{Z}$ kuşağına ait bireylerin en fazla 24 yaşında olduğu düşünüldüğünde önümüzdeki süreçte $\mathrm{Z}$ kuşağı bireylerin sahip olduğu teknoloji kullanım avantajı ve bilgiye erişimdeki üstünlükleri eğitim, tüketim, kültür vb. konularda önemli değişikliklere neden olacağını söylemek yanlış olmayacaktır. Bu değişime hazırlıklı olmayan kurum ve kuruluşlarda ise önemli çatışmaların ortaya çıkabileceğini, marka ve firmaların ise çok zor durumlarla karşı kaşıya kalacaklarını tahmin etmek zor olmayacaktır.

Ülkemizde 24 milyondan fazla bebek, çocuk, ergen ve ilk gencin yakın gelecekte tüketici sıfatıyla satın alma kararı vereceğini ya da bazılarının hâlihazırda zaten kendi kararlarını vermeye başladığını söylemek mümkündür (Kuran, 2018:132).

2016 yılında yapılan Y ve Z kuşaklarının satın alma karar tarzlarının karşılaştırıldı $\breve{g}_{1}$ bir çalışmada Z kuşağı bireylerinin Y kuşağı bireylerine göre daha fazla hedonik-eğlence odaklı oldukları belirlenmiştir (Kavalcı ve Ünal, 2016:1048). Z ve X kuşaklarının hedonik satın alma davranışlarının karşılaştıııldığı bir araştırmada, Z kuşağının ilgilerine hitap eden, yeni ve farklı ürünleri bulabilecekleri her yönüyle iyi düzenlenmiş bir atmosferi olan alışveriş ortamlarında alışveriş yapmaktan daha fazla tatmin olmuş şekilde ayrılabilecekleri belirtilmiştir. Ayrıca bu tür ortamların bu kuşağın macera arayışına daha çok hitap edebileceği, fikir edinme ve başkalarını mutlu etme yönlü hedonik eğilimlerine cevap vereceği de ifade edilmiştir (Can ve Yiğit, 2018:839). Kuşakların satın alma davranışları ile ilgili yapılan bir araştırmada, Z kuşağının alışverişler merkezlerinde daha çok alışveriş yaptığı, interneti en fazla kullanan kuşak olduğu, ürünün fiyatına en fazla dikkat eden kuşak olduğu tespit edilmiştir (Sarı ve Harta, 2018). Konuyla ilgili benzer bir araştırmada ise Z kuşağına mensup tüketicilerin Y kuşağına göre daha fazla mükemmeliyetçilik, marka, moda, düşünmeden/dikkatsiz alışveriş, bilgi karmaşası ve alışverişten kaçınma odaklı oldukları tespit edilmiştir (Özden, 2019:17).

\section{Araştırma Yöntemi}

Z kuşağı tüketicilerin satın alma karar tarzlarının incelenmesi amacıyla yapılan bu araştırma kapsamında Kastamonu ilinde Ocak-Şubat 2019 tarihleri arasında kolayda örnekleme yöntemine göre belirlenmiş 2000 yılı ve sonrasında dünyaya gelmiş 384 öğrenci ile yüz yüze anket yapılmıștır. Ancak 64 anket cevapların okunmaması, eksik veya özensiz doldurulması nedeniyle analiz dışında tutulmuştur. Sonuç olarak analize dâhil edilen 320 kişi araştırmanın örneklemini 
oluşturmuştur. Araştırma kapsamında öncelikle 30 öğrenciye anket uygulanmış soruların anlaşılırlığı konusunda sorun olmadığı tespit edildikten sonra diğer anketlerin dağıtımına geçilmiştir. Oluşturulan anket formu iki bölüm olarak tasarlanmıştır. İlk bölümde katılımcıların demografik özellikleri ve alışveriş alışkanlıklarına yönelik sorular yer alırken ikinci bölümde katılımcıların satın alma karar tarzlarının öğrenilmesine yönelik ölçek ifadeleri yer almaktadır. İkinci bölümde kullanılan ölçek ifadelerinde Sproles ve Kendall (1986) tarafından geliştirilen ve Dursun vd. (2013) tarafından Türkiye'de güvenilirlik ve geçerliliği test edilen tüketici satın alma karar tarzları ölçeği kullanılmıştır. Hazırlanan anket formundaki ölçeklerle ilgili ifadeler için 5'li Likert ölçeği kullanılmıştır. 5'li Likert ölçeğinde değerlendirme; (1) Kesinlikle katılmıyorum, (2) Katılmıyorum, (3) Kararsızım, (4) Katılıyorum, (5) Kesinlikle katılıyorum şeklinde kodlanmıştır. Araştırmalarda çarpıklık ve basıklık ölçüsü $+1,5$ veya $-1,5$ aralığında değerler almış olan grupların normal dağılım gösterdiği kabul edilmektedir (Tabachnick \& Fidel, 2013). Araştırmadaki boyutların basıklık çarpıklık değerlerine bakıldığında belirtilen değerler arasında olması nedeniyle boyutların tamamının normal dağılım gösterdiği söylenebilecektir. Bu nedenle araştırmada elde edilen verilere frekans analizi, açıklayıcı faktör analizi yapılmıştır. Araştırma kapsamında oluşturulan hipotezler ise Tek Yönlü Varyans (Anova) analizi ve bağımsız örneklem T-testi aracılığı ile test edilmiştir. Araştırmada ölçeklerin güvenirlikleri Cronbach Alpha katsayı ile ölçülmüştür. Verilerin analizinde SPSS programından yararlanılmıştır. Z kuşağı tüketicilerin satın alma karar tarzlarının incelenmesi amacı ve yapılan literatür incelemesi doğrulusunda aşağıdaki hipotezler oluşturulmuştur:

- $\mathrm{H}_{1}:$ Katılımcıların yaşları ile satın alma karar tarzları arasında anlamlı bir farklılık vardır.

- $\mathrm{H}_{2}$ : Katılımcıların aylık ortalama kişisel gelirleri ile satın alma karar tarzları arasında anlamlı bir farklılık vardır.

- $\mathrm{H}_{3}$ : Katılımcıların aylık ortalama aile kişisel gelirleri ile satın alma karar tarzları arasında anlamlı bir farklılık vardir.

- $\mathrm{H}_{4}$ : Katılımcıların alışveriş sıklıkları ile satın alma karar tarzları arasında anlamlı bir farklılık vardır.

- $\mathrm{H}_{5}$ : Katılımcıların alışveriş partnerleri ile karar satın alma karar arasında anlamlı bir farklılık vardır.

- $\mathrm{H}_{6}$ : Katılımcıların alışverişten etkilendiği gruplar ile satın alma karar tarzları arasında anlamlı bir farklılık vardır.

- $\mathrm{H}_{7}$ : Katılımcıların cinsiyetleri ile satın alma karar tarzları arasında anlamlı bir farklılık vardır.

\section{Bulgular}

Bu bölümde katılımcıların demografik özellikleri ve satın alma karar tarzlarına yönelik açıklayıcı faktör analizi ile satın alma karar tarzları açısından demografik özellikleri ve alışveriş alışkanlıkları arasında farklılık olup olmadığını belirlemeye yönelik yapılan Varyans Analizi ve T-testi bulguları yer almaktadır.

\subsection{Demografik Özellikler}

Bu bölümde katılımcıların demografik özelliklerine ve alışveriş alışkanlıklarına yönelik bilgiler yer almaktadır.

Tablo 3. Katılımcıların Demografik Özellikleri

\begin{tabular}{|c|c|c|c|c|c|}
\hline Cinsiyet & $\boldsymbol{F}$ & $\%$ & Anne Ĕgitim Düzeyi & $\boldsymbol{F}$ & $\%$ \\
\hline Erkek & 169 & 52,8 & İlkokul & 110 & 34,1 \\
\hline Kadın & 151 & 47,2 & Ortaokul & 61 & 19,1 \\
\hline Yaş & $\boldsymbol{F}$ & $\%$ & Lise & 106 & 33,1 \\
\hline 14 & 58 & 18,1 & Lisans ve Üzeri & 43 & 13,4 \\
\hline 15 & 70 & 21,9 & Baba Ĕgitim Düzeyi & $F$ & $\%$ \\
\hline 16 & 88 & 27,5 & İlkokul & 54 & 16,9 \\
\hline 17 & 73 & 22,8 & Ortaokul & 55 & 17,2 \\
\hline 18 & 31 & 9,7 & Lise & 141 & 44,1 \\
\hline Aile Aylık Ort. Gelir & $\boldsymbol{F}$ & $\%$ & Lisans ve Üzeri & 70 & 21,9 \\
\hline 1600 TL ve Alt1 & 23 & 7,2 & Anne Meslek & $F$ & $\%$ \\
\hline $1601 \mathrm{TL}-2500 \mathrm{TL}$ & 68 & 21,3 & Ev Hanımı & 211 & 65,9 \\
\hline $2501 \mathrm{TL}-3500 \mathrm{TL}$ & 74 & 23,1 & Özel Sektör Çalışanı & 26 & 8,1 \\
\hline $3501 \mathrm{TL}-4500 \mathrm{TL}$ & 70 & 21,9 & $\begin{array}{l}\text { Serbest Meslek(Avukat, Dr, Mali } \\
\text { Müşavir) }\end{array}$ & 18 & 5,6 \\
\hline 4501 TL ve Üzeri & 85 & 26,6 & Kamu Sektörü Çalışanı & 33 & 10,3 \\
\hline Aylık Kişisel Ort. Gelir & $\boldsymbol{F}$ & $\%$ & Esnaf & 18 & 5,6 \\
\hline 500 TL ve Alt1 & 186 & 58,1 & Diğger & 14 & 4,4 \\
\hline $501 \mathrm{TL}-750 \mathrm{TL}$ & 86 & 26,9 & Baba Meslek & $\boldsymbol{F}$ & $\%$ \\
\hline
\end{tabular}




\begin{tabular}{|l|l|l|l|l|l|}
\hline 751 TL-1000 TL & 17 & 5,3 & $\begin{array}{l}\text { Serbest Meslek(Avukat, Dr, Mali } \\
\text { Müşavir) }\end{array}$ & 45 & 14,1 \\
\hline 1001 TL ve Üzeri & 31 & 9,7 & Özel Sektör Çalışanı & 74 & 23,1 \\
\hline En Uzun Yaş. Yer Yeri & $\boldsymbol{F}$ & $\mathbf{\%}$ & Kamu Sektörü Çalışanı & 73 & 22,8 \\
\hline Köy & 57 & 17,8 & Esnaf & 87 & 27,2 \\
\hline İlçe & 75 & 23,4 & Çiftçi & 22 & 6,9 \\
\hline Şehir & 166 & 51,9 & Diğer & 19 & 5,9 \\
\hline Büyükşehir & 22 & 6,9 & & & \\
\hline Toplam & $\mathbf{3 2 0}$ & $\mathbf{1 0 0}$ & Toplam & $\mathbf{3 2 0}$ & $\mathbf{1 0 0}$ \\
\hline
\end{tabular}

Tablo 3'te yer alan bilgiler incelendiğinde araştırmanın 320 katılımcıdan oluştuğu, bu katılımcıların çoğunluğunun erkek olduğu, 16 yaşında olanların çoğunluğu oluşturduğu, yine aylık kişisel gelirlerinin büyük çoğunluğun 500 TL ve altında olduğu görülmektedir. Yine tabloya bakıldığında katılımcıların annelerinin ilkokul mezunu ve ev hanımı olduğu babalarının ise lise mezunu ve esnaf oldukları görülmektedir. Katılımcıların en uzun yaşadıkları yerin ise şehir olduğu yine tablodan anlaşıllmaktadır.

Tablo 4. Katılımcıların Alışveriş Alışkanlıkları

\begin{tabular}{|c|c|c|c|c|c|}
\hline Alışveriş yapma sıklığınız? & $\boldsymbol{F}$ & $\%$ & $\begin{array}{c}\text { Alışveriş öncesi araştırmanızı } \\
\text { nasıl yaparsınız? }\end{array}$ & $\boldsymbol{F}$ & $\%$ \\
\hline Haftada bir & 74 & 23,1 & Arkadaşlarıma sorarım & 55 & 17,2 \\
\hline İki haftada bir & 53 & 16,6 & İnternette araştırma yaparım & 122 & 38,1 \\
\hline Ayda bir & 32 & 10,0 & Mağazaları dolaşırım & 110 & 34,4 \\
\hline İhtiyacım olduğunda & 151 & 47,2 & Diğer & 33 & 10,3 \\
\hline Diğer & 10 & 3,1 & $\begin{array}{l}\text { Alışverişlerinizde en çok } \\
\text { kimlerden etkilenirsiniz? }\end{array}$ & $\boldsymbol{F}$ & $\%$ \\
\hline Alışverişe kiminle çıkarsınız? & $F$ & $\%$ & Arkadaşlarımdan & 114 & 35,6 \\
\hline Yaln1z & 53 & 16,6 & Aile üyelerimden & 106 & 33,1 \\
\hline Aileden biri ile & 170 & 53,1 & Sosyal medya ünlülerinden & 32 & 10,0 \\
\hline Arkadaşlarımla & 83 & 25,9 & Geleneksel ünlülerden & 25 & 7,8 \\
\hline Diğer & 14 & 4,4 & TV reklamlarından & 28 & 8,8 \\
\hline $\begin{array}{c}\text { Alışverişlerinizi çoğunlukla } \\
\text { nereden yaparsınız? }\end{array}$ & $F$ & $\%$ & Diğer & 15 & 4,7 \\
\hline Alışveriş merkezi & 163 & 50,9 & $\begin{array}{c}\text { Satın alma kararınızı en çok ne } \\
\text { etkiler? }\end{array}$ & $\boldsymbol{F}$ & $\%$ \\
\hline Cadde mağazaları & 109 & 34,1 & Fiyat & 102 & 31,9 \\
\hline İnternet üzerinden & 37 & 11,6 & Kalite & 126 & 39,4 \\
\hline Mobil uygulama üzerinden & 3 & 0,9 & Marka & 34 & 10,6 \\
\hline Diğer & 8 & 2,5 & Tasarım & 52 & 16,3 \\
\hline $\begin{array}{c}\text { Kredi kartı kullanıyor } \\
\text { musunuz? }\end{array}$ & $\boldsymbol{F}$ & $\%$ & Diğer & 6 & 1,9 \\
\hline Evet & 110 & 34,4 & $\begin{array}{c}\text { Alışverişe çıkmadan önce liste } \\
\text { yapar misını?? }\end{array}$ & $F$ & $\%$ \\
\hline \multirow[t]{2}{*}{ Hayır } & 210 & 65,6 & Evet & 89 & 27,8 \\
\hline & & & Hayır & 231 & 72,2 \\
\hline Toplam & 320 & 100 & Toplam & 320 & 100 \\
\hline
\end{tabular}

Tablo 4'te katılımcıların alışveriş alışkanlıklarına yönelik bilgiler yer almaktadır. Tablo incelendiğinde katılımcıların büyük çoğunluğunun ihtiyacı olması durumunda alışveriş yaptıkları, yine büyük çoğunluğun alışverişe aileden biri ile çıktığı, alışverişlerini çoğunlukla alışveriş merkezlerinden yaptığı görülmektedir. Yine tablo incelendiğinde büyük çoğunluğun kredi kartı kullanmadığı, alışverişe çıkmadan önce liste yapmadığı, satın alacağı ürünlerle ilgili internetten araştırma yaptığı, alışverişlerinde daha çok arkadaşlarından etkilendiği ve son olarak satın alma kararını kalite ve fiyatın daha çok etkilediği anlaşılmaktadır. 


\subsection{Faktör Analizi}

Bu bölümde katılımcıların satın alma karar tarzlarını belirleyebilmek için yapılan açıklayıcı faktör analizi bulguları yer almaktadır.

Tablo 5. Kmo ve Bartlett's Test

\begin{tabular}{|l|l|r|}
\hline \multicolumn{2}{|l|}{ Kaiser-Meyer-Olkin Measure of Sampling Adequacy. } &, 844 \\
\hline \multirow{3}{*}{ Bartlett's Test of Sphericity } & Approx. Chi-Square & 2792,117 \\
\cline { 2 - 3 } & df & 325 \\
\cline { 2 - 3 } & Sig. &, 000 \\
\hline
\end{tabular}

Analiz sonucunda, elde edilen Bartlett Küresellik Testi (Bartlett's Test of Sphericity) değerleri değişkenler arasında faktör analizi yapmaya yeterli düzeyde ilişki olduğunu göstermektedir ( $p=.000$, Ki Kare 2792,117, Serbestlik Derecesi 320).

Tablo 6. Faktör Analizi

\begin{tabular}{|c|c|c|c|c|c|c|c|}
\hline & \multicolumn{7}{|c|}{ Faktörler } \\
\hline & 1 & 2 & 3 & 4 & 5 & 6 & 7 \\
\hline \multicolumn{8}{|l|}{ Kalite Odaklılık } \\
\hline Genellikle, en iyi kaliteye sahip ürünü almaya çalışırım. & ,843 & & & & & & \\
\hline $\begin{array}{l}\text { Aldığım ürünlerin yüksek kalitede olması benim için çok } \\
\text { önemlidir. }\end{array}$ & 816 & & & & & & \\
\hline $\begin{array}{l}\text { Bir ürün satın alırken en iyi olanı ya da mükemmel olanı satın } \\
\text { almaya çalışırım. }\end{array}$ & 806 & & & & & & \\
\hline En iyi kaliteye sahip ürünü seçmek için özel çaba sarf ederim. & ,727 & & & & & & \\
\hline $\begin{array}{l}\text { Satın aldığım ürünlerle ilgili standartlarım ve beklentilerim çok } \\
\text { yüksektir. }\end{array}$ & ,468 & & & & & & \\
\hline \multicolumn{8}{|l|}{ Marka Odaklılık } \\
\hline Bir ürünün fiyatı ne kadar yüksek ise o ürün o kadar kalitelidir. & &, 816 & & & & & \\
\hline $\begin{array}{l}\text { Güzel görünümlü ve özenle düzenlenmiş mağazalar en iyi } \\
\text { ürünleri satarlar. }\end{array}$ & & ,766 & & & & & \\
\hline Reklamı en çok yapılan markalar genellikle en iyi seçimdir. & & ,602 & & & & & \\
\hline En çok satılan markaları satın almayı tercih ederim. & & ,477 & & & & & \\
\hline Tercihimi genellikle pahalı markalardan yana kullanırım. & &, 502 & & & & & \\
\hline \multicolumn{8}{|l|}{ Moda Odaklılık } \\
\hline Gardırobumu değişen modaya uygun tutarım. & & & ,785 & & & & \\
\hline Genellikle son moda bir ya da daha fazla kıyafetim vardır. & & & ,622 & & & & \\
\hline $\begin{array}{l}\text { Dikkat çekici, modaya uygun bir stilimin olması benim için } \\
\text { önemlidir. }\end{array}$ & & & 621 & & & & \\
\hline \multicolumn{8}{|l|}{ Ĕglence- Haz Odaklılık } \\
\hline $\begin{array}{l}\text { Alışverişe çıkmak hayatımın en eğlenceli aktivitelerinden } \\
\text { biridir. }\end{array}$ & & & &, 755 & & & \\
\hline Yeni ve heyecan verici şeyler satın almak eğlencelidir. & & & & 665 & & & \\
\hline Sırf eğlenmek için alışverişe çıkmak hoşuma gider. & & & & ,659 & & & \\
\hline \multicolumn{8}{|l|}{ Bağlılık-Sadakat } \\
\hline Defalarca satın aldığım favori markalarım vardır. & & & & & ,737 & & \\
\hline $\begin{array}{l}\text { Bir kez sevdiğim bir ürün/marka bulduğumda onu asla } \\
\text { değiştirmem. }\end{array}$ & & & & & ,699 & & \\
\hline Her alışverişe çıktığımda aynı mağazalara giderim. & & & & & ,605 & & \\
\hline \multicolumn{8}{|l|}{ Dikkatsizlik ve Çeşit Karmaşası } \\
\hline $\begin{array}{l}\text { Genellikle sonradan yapmamış olmayı umduğum, dikkatsiz } \\
\text { satın almalar gerçekleştiririm. }\end{array}$ & & & & & &, 747 & \\
\hline Satın alırken plansız hareket ederim. & & & & & & ,652 & \\
\hline $\begin{array}{l}\text { Satın alma gerçekleştirirken çok fazla düşünmem/çok ilgi } \\
\text { göstermem. }\end{array}$ & & & & & &, 588 & \\
\hline
\end{tabular}




\begin{tabular}{|c|c|c|c|c|c|c|c|}
\hline $\begin{array}{l}\text { Farklı ürünler hakkında sahip olduğum her bilgi kafamın } \\
\text { karışmasına neden olur. }\end{array}$ & & & & & &, 524 & \\
\hline \multicolumn{8}{|l|}{ Fiyat Odaklılık } \\
\hline $\begin{array}{l}\text { Tercihimi genellikle en düşük fiyatlı ürünlerden yana } \\
\text { gerçekleştiririm. }\end{array}$ & & & & & & & ,787 \\
\hline $\begin{array}{l}\text { İndirim olduğunda elimden geldiğince satın alma } \\
\text { gerçekleştiririm. }\end{array}$ & & & & ,382 & & &, 539 \\
\hline $\begin{array}{l}\text { Paramın karşılığında en yüksek değeri elde etmek için dikkatli } \\
\text { davranırım. }\end{array}$ & ,358 & & & & & & , 473 \\
\hline Açıklanan Varyans & 12,721 & 9,621 & 8,754 & 8,483 & 7,906 & 7,701 & 6,133 \\
\hline Toplam Açıklanan Varyans & \multicolumn{7}{|r|}{61,319} \\
\hline Cronbach Alfa & ,829 & ,784 &, 740 & ,655 & ,677 & 608 & ,580 \\
\hline Toplam Cronbach Alfa & \multicolumn{7}{|r|}{874} \\
\hline
\end{tabular}

Araştırmada katılımcıların satın alma karar tarzlarını belirlemek amacıyla açıklayıcı faktör analizi yapılmıştır. Faktör analizinde öz değeri (eigen value) 1'den daha büyük ve minimum yükleme büyüklüğü olarak 0.35 kriteri kullanılmıştır. Bunun sebebi bir maddenin bir yapıyı ya da faktörü iyi ölçtüğünü söyleyebilmek için bu faktör yükünün değerinin 0.30 ya da bu değerin üstünde bir değer olmas1 gerekliliğindendir (Kline, 1994, Akt.,Karaman, 2015:31). Verilerin analizinden önce ölçeklerin güvenirliklerini ölçmek için bütün maddelerin Cronbach Alfa katsayılarına bakılmıştır. Ölçekte toplamda 41 ifade yer almasına rağmen Scale if item deleted sütunundan bakılarak 4 ifade ölçeğin güvenirliğini düşürmesi, 6 ifade ise farklı faktörlerin altında yer alması nedeniyle analizden çıkartılmıştır. Bu doğrultuda nihai faktör analizi 29 ifade ile gerçekleştirilmiştir. Sonuç olarak araştırmada Z kuşağı tüketicilerin satın alma karar tarzları ile ilgili olarak toplamda 29 ifadeden oluşan 7 boyut olarak ortaya çıkmıştır. Bu boyutlar; Kalite Odaklılık (5 ifade), Marka Odaklılık (5 ifade), Moda Odaklılık (3 ifade), Eğlence- Haz Odaklılık (3 ifade), Bağlılık-Sadakat (3 ifade), Dikkatsizlik ve Çeşit Karmaşası (4 ifade) ile Fiyat Odaklılık (3 ifade). Orjinal ölçekte Dikkatsizlik ve Çeşit Karmaşası iki ayrı faktör olarak toplam 8 faktör olarak ortaya çıkmıştır. Örneklem farklılığı nedeniyle bu iki faktör araştırmada tek faktör altında toplanmıştır. Bu faktörler katılımcıların satın alma karar tarzlarının toplamda \%61,319'nu açıklamaktadır. Açıklanmayan diğer kısım ise araştırmada yer almayan değişkenler tarafından açıklanmaktadır. Boyutların güvenilirlik değeri olan Cronbach Alfa ise ,874 olarak tespit edilmiştir.

\subsection{Varyans Analizi (One-Way ANOVA)}

Bu bölümde katılımcıların satın alma karar tarzları ile demografik özellikleri başta olmak üzere alışveriş alışkanlıkları arasında istatistiksel açıdan farklılık olup olmadığını belirlemek amacıyla yapılan Tek Yönlü Varyans analizi bulguları yer almaktadır. Yapılan Tek Yönlü Varyans analizi sonucunda katılımcıların yaşları arasında haz ve eğlence odaklılık boyutu açısından, aylık kişisel ortalama gelirleri arasında marka odaklılık boyutu açısından, aylık aile ortalama gelirleri arasında kalite odaklılık açısından, katılımcıların cinsiyetleri arasında haz ve eğlence odaklılık boyutları açısından istatistiksel olarak farklılık tespit edilmiştir. Yine Tek Yönlü Varyans analizi sonucunda katılımcıların alışveriş sıklıkları arasında marka odaklılık, marka bağlılığı ve dikkatsizlik-kafa karışıklığı boyutları açısından, alışveriş partnerleri arasında moda odaklılık ile haz ve eğlence odaklılık boyutları açısından, alışverişten etkilendiği gruplar arasında moda odaklılık ile marka bağlılığı boyutları açısından istatistiksel olarak farklılıklar ortaya çıkmıştır. Diğer boyutlar açısından ise anlamlı bir farklılık tespit edilmemiştir. Bu nedenle bu bölümde sadece farklılık tespit edilen boyutlar ve farklılığın ortaya çıktığ gruplara ilişkin bilgilere yer verilmiştir.

Tablo 7. Satın Alma Karar Tarzları İle Katılımcıların Yaşları Anova Testi

\begin{tabular}{|c|c|c|c|c|c|c|c|c|}
\hline Faktörler & \multicolumn{2}{|c|}{ Gruplar } & $N$ & Ort. & Std. Hata & $F$ & Sig. & Farklılık \\
\hline \multirow{5}{*}{$\begin{array}{l}\text { Haz ve Eğlence } \\
\text { Odaklılık }\end{array}$} & $\mathrm{A}$ & 14 & 58 & 3,0230 &, 12855 & \multirow{5}{*}{5,346} & \multirow{5}{*}{,000 } & \multirow{5}{*}{$\begin{array}{l}E>A \\
E>C \\
E>D\end{array}$} \\
\hline & B & 15 & 70 & 3,1381 & 12219 & & & \\
\hline & $\mathrm{C}$ & 16 & 88 & 2,9280 & ,08458 & & & \\
\hline & $\mathrm{D}$ & 17 & 73 & 2,7169 & 10377 & & & \\
\hline & $E$ & 18 & 31 & 3,5914 & ,19227 & & & \\
\hline
\end{tabular}

Katılımcıların yaşları arasında satın alma karar tarzları açısından Tablo 7'de görüldüğü gibi sadece haz ve eğlence odaklılık faktörü açısından istatistiksel olarak anlamlı farklılık tespit edilmiştir. Bu durumda $(\mathrm{p}<0,05)$ olması nedeniyle $\mathrm{H}_{1}$ hipotezi kabul edilmiştir. Farklılıkların hangi gruplar arasında olduğunu tespit etmek amacıyla ise Tukey testi 
yapılmıştır. Tukey testi sonuçlarına göre ise 18 yaşında olanların 14, 16 ve 17 yaşında olanlara göre haz ve eğlence odaklılık ortalamaları daha yüksek tespit edilmiştir. Bu sonuç 18 yaşında olanların yetişkin bireyler olarak kendi alışveriş kararlarını haz ve eğlence odaklılık olarak net biçimde ortaya koydukları biçiminde yorumlanabilecektir. Ayrıca Z kuşağı bireyler her ne kadar aynı kuşak altında ele alınsalar dahi bu sonuçlar kendi içlerinde de farklılıklar olduğunu Z kuşağının homojen bir yapıda olmadığını ortaya koymaktadır.

Tablo 8. Satın Alma Karar Tarzları İle Katılımcıların Aylık Ort. Kişisel Gelirleri Anova Testi

\begin{tabular}{|c|c|c|c|c|c|c|c|c|}
\hline Faktörler & \multicolumn{2}{|r|}{ Gruplar } & & $N \quad$ Ort. & $\begin{array}{c}\text { Std. } \\
\text { Hata }\end{array}$ & $F$ & Sig. & Farklılık \\
\hline \multirow{4}{*}{$\begin{array}{c}\text { Marka } \\
\text { Odaklılık }\end{array}$} & A & 500 TL ve Alt1 & 186 & 2,5935 & 05956 & \multirow{4}{*}{4,356} & \multirow{4}{*}{,005 } & \multirow{4}{*}{$\begin{array}{l}D>A \\
D>B\end{array}$} \\
\hline & B & $501 \mathrm{TL}-750 \mathrm{TL}$ & 86 & 2,6070 & ,09533 & & & \\
\hline & $\mathrm{C}$ & $751 \mathrm{TL}-1000 \mathrm{TL}$ & 17 & 2,7647 & ,24925 & & & \\
\hline & $\mathrm{D}$ & 1000 TL ve Üzeri & 31 & 3,1742 & , 15705 & & & \\
\hline
\end{tabular}

Yapılan varyans analizi sonucunda katılımcıların satın alma karar tarzları açısından aylık ortama kişisel gelirleri arasında istatistiksel olarak farklılık tespit edilmiştir. $\mathrm{Bu}$ durumda $(\mathrm{p}<0,05)$ olması nedeniyle $\mathrm{H}_{2}$ hipotezi kabul edilmiştir. Farklılıkların hangi gruplar arasında olduğunu tespit etmek amacıyla yapılan Tukey testi sonucunda ise $751 \mathrm{TL}-1000 \mathrm{TL}$ arasında geliri olanların 500 TL ve altında geliri olanlara ve 501 TL -750 TL arasında geliri olanlara göre marka bağlılığ faktör ortalamaları daha yüksek bulunmuştur. Bu bulgu da belli bir düzeyde geliri olanların alışverişlerinde sürekli aynı markayı satın aldıkları şeklinde yorumlanabilecektir.

Tablo 9. Satın Alma Karar Tarzları İle Katılımcıların Aylık Ort. Aile Gelirleri Anova Testi

\begin{tabular}{|c|c|c|c|c|c|c|c|c|}
\hline Faktörler & & Gruplar & $N$ & Ort. & $\begin{array}{l}\text { Std. } \\
\text { Hata }\end{array}$ & $\boldsymbol{F}$ & Sig. & Farklılık \\
\hline \multirow{5}{*}{$\begin{array}{c}\text { Kalite } \\
\text { Odaklılık }\end{array}$} & $\bar{A}$ & 1600 TL ve Alt1 & 23 & 3,0174 & , 15498 & \multirow{5}{*}{2,130} & \multirow{5}{*}{, 017} & \multirow{5}{*}{$\mathrm{D}>\mathrm{B}$} \\
\hline & $\mathrm{B}$ & $1601 \mathrm{TL}-2500 \mathrm{TL}$ & 68 & 2,9618 & ,09919 & & & \\
\hline & $\mathrm{C}$ & $2501 \mathrm{TL}-3500 \mathrm{TL}$ & 74 & 3,2162 & ,09549 & & & \\
\hline & $\mathrm{D}$ & 3501 TL-4500 TL & 70 & 3,3886 & ,11948 & & & \\
\hline & $E$ & 4501 TL ve Üzeri & 85 & 3,1788 & ,10784 & & & \\
\hline
\end{tabular}

Yapılan varyans analizi sonucunda katılımcıların satın alma karar tarzları açısından ailelerinin aylık ortama gelirleri arasında istatistiksel olarak farklılık tespit edilmiştir. Bu durumda $(\mathrm{p}<0,05)$ olması nedeniyle $\mathrm{H}_{3}$ hipotezi kabul edilmiştir. Farklılıkların hangi gruplar arasında olduğunu tespit etmek amacıyla yapılan Tukey testi sonucunda ise 3501 TL-4500 TL arasında geliri olanların 1601 TL-2500 TL arasında geliri olanlara göre kalite odaklılık faktör ortalaması daha yüksek bulunmuştur. $\mathrm{Bu}$ bulgu da ailesi belli bir gelir düzeyine sahip katılımcıların alışverişlerinde daha kalite odaklı hareket ettiklerini göstermektedir.

Tablo 10. Satın Alma Karar Tarzları İle Katılımcıların Alışveriş Sıklığı Anova Testi

\begin{tabular}{|c|c|c|c|c|c|c|c|c|}
\hline Faktörler & & Gruplar & $N$ & Ort. & $\begin{array}{c}\text { Std. } \\
\text { Hata }\end{array}$ & $\boldsymbol{F}$ & Sig. & Farklılık \\
\hline \multirow{5}{*}{ Moda Odaklılık } & A & Haftada bir & 75 & 2,9730 & ,13078 & \multirow{5}{*}{4,280} & \multirow{5}{*}{,002 } & \multirow{5}{*}{$A>D$} \\
\hline & $\mathrm{B}$ & İki haftada bir & 53 & 2,8553 & ,09734 & & & \\
\hline & $\mathrm{C}$ & Ayda bir & 32 & 2,7813 & ,13848 & & & \\
\hline & $\mathrm{D}$ & $\begin{array}{l}\text { İhtiyacim } \\
\text { olduğunda }\end{array}$ & 151 & 2,5132 & ,07476 & & & \\
\hline & $\mathrm{E}$ & Diğer & 10 & 2,2000 & ,28631 & & & \\
\hline \multirow{5}{*}{ Bağl1lık Sadakat } & $\mathrm{A}$ & Haftada bir & 75 & 3,2658 & ,11311 & \multirow{5}{*}{6,438} & \multirow{5}{*}{,000 } & \multirow{5}{*}{$\begin{array}{l}A>D \\
A>E\end{array}$} \\
\hline & $\mathrm{B}$ & İki haftada bir & 53 & 3,1572 & ,11933 & & & \\
\hline & $\mathrm{C}$ & Ayda bir & 32 & 3,0521 & ,13562 & & & \\
\hline & $\mathrm{D}$ & $\begin{array}{l}\text { İhtiyacim } \\
\text { olduğunda }\end{array}$ & 151 & 2,9029 & ,06816 & & & \\
\hline & $\mathrm{E}$ & Diğer & 10 & 1,9333 & ,23727 & & & \\
\hline & $\mathrm{A}$ & Haftada bir & 75 & 3,0304 & ,10979 & \multirow[b]{3}{*}{1,701} & \multirow[b]{3}{*}{, 150} & \multirow[b]{3}{*}{$A>D$} \\
\hline & $\mathrm{B}$ & İki haftada bir & 53 & 3,0079 & ,11196 & & & \\
\hline & $\mathrm{C}$ & Ayda bir & 32 & 2,6641 &, 10861 & & & \\
\hline
\end{tabular}




\begin{tabular}{|c|c|c|c|c|c|c|}
\hline \multirow[t]{2}{*}{$\begin{array}{c}\text { Dikkatsizlik - Kafa } \\
\text { karışıklığ1 }\end{array}$} & D & $\begin{array}{l}\text { İhtiyacim } \\
\text { olduğunda }\end{array}$ & 151 & 2,5861 & 06081 & \multirow[t]{2}{*}{$B>D$} \\
\hline & $\mathrm{E}$ & Diğer & 10 & 2,4000 & ,25604 & \\
\hline
\end{tabular}

Yapılan Varyans analizi sonucunda, katılımcıların satın alma karar tarzları ile alışveriş sıklıkları arasında istatistiksel olarak farklılık tespit edilmiştir. Bu durumda $(\mathrm{p}<0,05)$ olması nedeniyle $\mathrm{H}_{4}$ hipotezi kabul edilmiştir. Farklılıkların hangi gruplar arasında olduğunu tespit etmek amacıyla yapılan Tukey testi sonucunda ise, marka odaklılık faktöründe haftada bir alışveriş yapanların ihtiyaç olması durumunda alışveriş yapanlara göre moda odaklılık ortalamaları daha yüksek çıkmıştır. Bu sonuç her hafta çeşitli ürün gruplarında yeni ürünleri gören tüketicilerin sadece ihtiyaç durumunda alışveriş yapanlara göre daha fazla moda ürünleri takip ettikleri şeklinde yorumlanabilecektir. Yine bağlılık faktörü açısından bakıldığında ise haftada bir alışveriş yapanların ortalamaları ihtiyaç durumunda alışveriş yapanlara göre daha yüksek bulunmuştur. Bu sonuçta yine tüketicilerin her hafta aynı marka ya da mağazaya yönelik bağımlılıklarının bir sonucu olarak düşünülmektedir.

Son olarak dikkatsizlik ve kafa karışıklığı faktörü açısından bakıldığında ise haftada bir ve iki haftada bir alışveriş yapanların ihtiyaç olması durumunda alışveriş yapanlara göre ortalamaları daha yüksek bulunmuştur. Bu sonuç yukarıdaki bulgularla karşılaştırıldığında her hafta ya da iki hafta da bir alışveriş yapanların dikkatsiz biçimde alışveriş yaptığı ve yaptığı alışveriş sonrası çeşitli pişmanlıklar ve kafa karışıklığı yaşadığı şeklinde yorumlanabilecektir.

Tablo 11. Satın Alma Karar Tarzları İle Katılımcıların Alışveriş Partneri Anova Testi

\begin{tabular}{|c|c|c|c|c|c|c|c|c|}
\hline Faktörler & & Gruplar & $N$ & Ort. & Std. Hata & $\boldsymbol{F}$ & Sig. & Farklılık \\
\hline \multirow{4}{*}{ Moda Odaklılık } & A & Yalnız & 53 & 2,4717 & , 13572 & \multirow{4}{*}{4,102} & \multirow{4}{*}{,007 } & \multirow{4}{*}{$\begin{array}{l}\mathrm{C}>\mathrm{A} \\
\mathrm{C}>\mathrm{B}\end{array}$} \\
\hline & B & Aileden biri ile & 170 & 2,6147 & ,06790 & & & \\
\hline & $\mathrm{C}$ & Arkadaşlarımla & 83 & 2,9839 & , 10689 & & & \\
\hline & $\mathrm{D}$ & Diğer & 14 & 2,7619 & ,28265 & & & \\
\hline \multirow{4}{*}{$\begin{array}{c}\text { Haz /Eğlence } \\
\text { Odaklılık }\end{array}$} & A & Yaln1z & 53 & 2,8553 & , 13839 & \multirow{4}{*}{2,961} & \multirow{4}{*}{,032 } & \multirow{4}{*}{$\mathrm{C}>\mathrm{B}$} \\
\hline & B & Aileden biri ile & 170 & 2,9294 & ,07113 & & & \\
\hline & $\mathrm{C}$ & Arkadaşlarımla & 83 & 3,2691 & 10788 & & & \\
\hline & $\mathrm{D}$ & Diğer & 14 & 2,9762 &, 17633 & & & \\
\hline
\end{tabular}

Yapılan Varyans analizi sonucunda, katılımcıların satın alma karar tarzları ile alışveriş partnerleri arasında istatistiksel olarak farklılık tespit edilmiştir. $\mathrm{Bu}$ durumda $(\mathrm{p}<0,05)$ olması nedeniyle $\mathrm{H}_{5}$ hipotezi kabul edilmiştir. Farklılıkların hangi gruplar arasında olduğunu tespit etmek amacıyla yapılan Tukey testi sonucunda ise, alışverişe arkadaşları ile çıkanların yalnız ya da aileden biri ile çıkanlara göre faktör ortalamaları daha yüksek bulunmuştur. Bu sonuç katılımcıların arkadaşlarını, moda konusunda aile üyeleri ve kendilerinden daha yetkin gördüklerini göstermektedir. Yine haz ve eğlence faktörü açısından ortaya çıkan sonuca bakıldığında ise katılımcıların arkadaşları ile çıktıkları alışverişten aile üyelerinden biri ile çıktıkları alışverişten daha fazla haz ve keyif aldıkları yorumu yapılabilecektir.

Tablo 12. Satın Alma Karar Tarzları İle Katılımcıların Alışverişten Etkilendiği Gruplar Anova Testi

\begin{tabular}{|c|c|c|c|c|c|c|c|c|}
\hline Faktörler & & Gruplar & $N$ & Ort. & Std. Hata & $\boldsymbol{F}$ & Sig. & Farklılık \\
\hline \multirow{6}{*}{$\begin{array}{c}\text { Moda } \\
\text { Odaklılık }\end{array}$} & $\mathrm{A}$ & Arkadaşlardan & 114 & 2,7135 & ,08561 & \multirow{6}{*}{2,901} & \multirow{6}{*}{,014 } & \multirow{6}{*}{$\begin{array}{l}C>B \\
C>D\end{array}$} \\
\hline & $\mathrm{B}$ & Aile üyelerinden & 106 & 2,6164 & ,09209 & & & \\
\hline & $\mathrm{C}$ & $\begin{array}{l}\text { Sosyal medya } \\
\text { ünlülerinden }\end{array}$ & 32 & 3,2188 & , 15953 & & & \\
\hline & $\mathrm{D}$ & Geleneksel ünlülerden & 25 & 2,3467 & , 16042 & & & \\
\hline & $\mathrm{E}$ & TV reklamlarından & 28 & 2,6429 & ,19086 & & & \\
\hline & $\mathrm{F}$ & Diğer & 15 & 2,6333 & ,28087 & & & \\
\hline \multirow{6}{*}{$\begin{array}{c}\text { Bağlilik ve } \\
\text { Sadakat }\end{array}$} & A & Arkadaşlardan & 114 & 2,9415 & ,08764 & \multirow{6}{*}{2,822} & \multirow{6}{*}{,016 } & \multirow{6}{*}{$\begin{array}{l}\mathrm{C}>\mathrm{A} \\
\mathrm{C}>\mathrm{D}\end{array}$} \\
\hline & $\mathrm{B}$ & Aile üyelerinden & 106 & 3,0283 & 07843 & & & \\
\hline & $\mathrm{C}$ & $\begin{array}{l}\text { Sosyal medya } \\
\text { ünlülerinden }\end{array}$ & 32 & 3,4583 & , 14948 & & & \\
\hline & $\mathrm{D}$ & Geleneksel ünlülerden & 25 & 2,7067 & 16922 & & & \\
\hline & $\mathrm{E}$ & TV reklamlarından & 28 & 2,8690 &, 16296 & & & \\
\hline & $\mathrm{F}$ & Diğer & 15 & 3,2889 & 29612 & & & \\
\hline
\end{tabular}

Yapılan Varyans analizi sonucunda, katılımcıların satın alma karar tarzları ile alışverişten etkilendiği taraflar arasında istatistiksel olarak farklılık tespit edilmiştir. $\mathrm{Bu}$ durumda $(\mathrm{p}<0,05)$ olması nedeniyle $\mathrm{H}_{6}$ hipotezi kabul edilmiştir. 
Farklılıkların hangi gruplar arasında olduğunu tespit etmek amacıyla yapılan Tukey testi sonucunda ise moda odaklılık faktör ortalamaları alışverişlerinde sosyal medya ünlülerinden etkilenenlerin aile üyelerinden ve geleneksel ünlülerden etkilenenlerden daha yüksek ortaya çıkmıştır. Bu bulgu katılımcıların sosyal medya ünlülerini daha fazla modayı yansıttıklarını düşündüklerini göstermektedir.

Bağlılık ve sadakat faktörü açısından bakıldığında ise yine sosyal medya ünlülerinden etkilenenlerin faktör ortalamaları arkadaşlarından ve geleneksel ünlülerden etkilenenlerden daha yüksek olduğu ortaya çıkmıştır. Bu bulgu da sosyal medya ünlülerinin takipçileri üzerinde marka sadakati oluşturmada geleneksel ünlülerden daha etkili olduklarını göstermektedir.

\subsection{T Testi Bulgulart}

Bu bölümde katılımcıların satın alma karar tarzları açısından cinsiyetleri arasında istatistiksel açısından farklılık olup olmadığını belirleyebilmek amacıyla yapılan T-testi bulguları yer almaktadır.

Tablo 13. Satın Alma Karar Tarzları İle Katılımcıların Cinsiyetleri T-Testi

\begin{tabular}{|c|l|c|c|c|c|c|c|}
\hline Faktör & Grup & $\boldsymbol{N}$ & Ort. & Std. Hata & $\boldsymbol{t}$ & $\boldsymbol{d}$ & $\boldsymbol{p}$ \\
\hline \multirow{2}{*}{$\begin{array}{c}\text { Haz ve Eğlence } \\
\text { Odaklılık }\end{array}$} & Erkek & 169 & 2,7988 &, 91307 & 4,329 & 318 &, 000 \\
\cline { 2 - 6 } & Kadın & 151 & 3,2406 &, 94920 & & & \\
\hline
\end{tabular}

Yapılan T-testi sonucunda, katılımcıların satın alma karar tarzları açısından cinsiyetleri arasında istatistiksel olarak farklılık tespit edilmiştir. Bu durumda $(\mathrm{p}<0,05)$ olması nedeniyle $\mathrm{H}_{7}$ hipotezi kabul edilmiştir. Farklılığın detaylarına bakıldığında kadınların haz ve eğlence odaklılık faktörü ortalamalarının erkeklerden daha yüksek olduğu tespit edilmiştir. Bu sonuç kadınların alışverişe daha fazla haz ve eğlence odaklı yaklaştıklarını göstermektedir.

\section{Sonuç ve Öneriler}

Z kuşağı tüketicilerin satın alma karar tarzlarının incelenmesi amacıyla gerçekleştirilen bu çalışma kapsamında ulaşılan sonuçlar ve sunulan öneriler aşağıda derlenmiştir:

Araştırmaya 14 ve 18 yaşları arasında dolayısı ile Z kuşağını temsil eden toplamda 320 öğrenci katılmıştır. Öğrencilerin yarıya yakını ihtiyacı olması durumunda alışveriş yapmayı tercih ederken, alışverişe çoğunlukla aileden biri ile çıkmayı tercih etmektedir. Alışverişlerini büyük oranda alışveriş merkezlerinde gerçekleştiren katılımcıların yine büyük çoğunluğu kredi kartı kullanmamaktadır. Bu sonuç Sarı ve Harta (2018) tarafından yapılan çalışmaların sonuçları ile benzerlik göstermektedir. Alışveriş öncesi araştırmalarını internet üzerinden gerçekleştiren katılımcıların yine alışverişlerinde en çok etkilendikleri kesim arkadaşları olmaktadır. Katılımcıların satın alma kararlarında etkili olan faktörler olarak ise ilk sırada kalite gelirken ikinci sırada ürünün fiyatı gelmektedir. Ortaya çıkan bu sonuç Hidvegi ve Kelemen-Erdös (2016), Smalej (2017) ile Sarı ve Harta (2018) tarafından yapılan çalışmaların sonuçlarla ile örtüşmektedir. Bu sonuçlar Z kuşağı bireylerin kendi gelirleri olmaması nedeniyle alışverişe aile üyelerinden biri ile çıktığını ancak arkadaşlarında ya da internette gördüğü bir ürünü satın aldığı şeklinde yorumlanabilecektir. Satın alma kararlarında kalite ve fiyatın öncelikli olması ise bu kuşağın üyelerinin rasyonel tüketici davranışları sergileme eğilimleri konusunda fikir vermektedir.

Katılımcıların satın alma karar tarzları açısından yapılan açıklayıcı faktör analizinde Kalite Odaklılık, Marka Odaklılık, Moda Odaklılık, Eğlence- Haz Odaklılık, Bağlılık-Sadakat, Dikkatsizlik ve Çeşit Karmaşası ile Fiyat Odaklılık olmak üzere yedi faktör olarak ortaya çıkmıştır. Bu faktörler katılımcıların satın alma karar tarzlarının toplamda \%61,319'nu açıklamaktadır. Katılımcıların satın alma karar tarzları açısından yaşları arasında sadece haz ve eğlence odaklılık açısından farklılık tespit edilmiştir. Buna göre 18 yaşında olanların, 14, 16 ve 17 yaşında olanlara göre alışverişe daha fazla haz ve eğlence odaklı yaklaştığı sonucuna ulaşılmıştır. Bu sonuç 18 yaşında olanların yetişkin bireyler olarak kendi alışveriş kararlarını haz ve eğlence odaklılık olarak net biçimde ortaya koydukları biçiminde değerlendirilmiştir. Kişisel gelir bağlamında ise aylık ortalama kişisel geliri 751 TL-1000 TL arasında olanların daha düşük gelire sahip olanlara göre alışverişlerinde daha fazla marka odaklı oldukları sonucuna ulaşılmıştır. Bu sonuç da geliri yüksek olanların alışveriş kararlarını marka ürünlerden yana kullanmak konusunda daha rahat olduklarını göstermektedir. Kalite odaklılık konusunda da benzer durum aile gelirinde de kendini göstermektedir.

Katılımcıların satın alma karar tarzları açısından cinsiyetleri bağlamında farklığa bakıldığında ise kadınların alışverişe erkeklerden daha çok haz ve eğlence odaklı yaklaştıkları sonucuna ulaşılmıştır. Bu sonuç aynı zamanda 
alışverişte bayanların erkeklerden daha çok eğlence ve haz unsularına önem verdiği şeklinde yorumlanabilecektir. Bu sonuç Smalej (2017:334) tarafından yapılan araştırmanın bulguları ile örtüşmektedir.

Katılımcıların satın alma karar tarzları açısından alışveriş sıklıkları arasında farklılık bulunmuştur. Farklılıklar incelendiğinde genel olarak her hafta alışveriş yapanların sadece ihtiyacı olması durumunda alışveriş yapanlara göre daha fazla moda odaklı, satın aldığı marka ya da mağazalara daha sadık ancak alışverişlerinde ise daha dikkatsiz ve kafalarının karışık olduğu sonucuna ulaşılmıştır. Bu sonuç her hafta ya da iki hafta da bir alışveriş yapanların dikkatsiz biçimde alışveriş yaptığı ve yaptığı alışveriş sonrası çeşitli pişmanlıklar ve kafa karışıklığı yaşadıkları şeklinde yorumlanabilecektir. Ayrıca bu sonuçlar henüz tam anlamıyla karakterleri oluşmayan ve gelişim çağında olan bu kuşak üyelerinin içinde bulunduğu psikolojik durumu yansıtması açısından önemli görülmektedir.

Katılımcıların alışverişe beraber çıktıkları kişiler arasında da satın alma karar tarzları açısından farklılık bulunmuştur. Yine farklılıklar incelendiğinde katılımcıların moda konusunda arkadaşlarını, aile üyelerinden ve kendilerinden daha yetkin gördükleri sonucuna ulaşılmıştır. Yine alışverişe arkadaşları ile çıkanların aile üyelerinden biri ile çıkanlardan daha fazla keyif aldıkları da ortaya çıkan bir diğer sonuç olmuştur. Z kuşağı üyeleri için arkadaşların satın alım kararlarında ki önemini ortaya koyması açısından bu sonuçların önemli olduğu düşünülmektedir.

Katılımcıların alışverişten etkilendikleri bireylerle ilgili yapılan Varyans analizi sonucunda ise katılımcıların sosyal medya ünlülülerini moda konusunda aile üyelerinden ve en önemlisi geleneksel ünlülerden daha fazla yetkin gördükleri sonucuna ulaşılmıştır. Yine benzer bir sonuç da katılımcılar sosyal medya ünlülerinin tavsiye ettiği marka ya da ürünlere arkadaşlarının ya da geleneksel ünlülerin tavsiye ettiği marka ve ürünlerden daha fazla bağlı ve sadık hissetmeleridir. Bu sonuçlar Lea vd. (2018:2) tarafından yapılan çalışma sonuçları ile örtüşmektedir. Bu sonuçlar Z kuşağı bireylerin satın alma karar tarzlarında sosyal medya ünlülerinin etkisini göstermesi açısından büyük önem taşımaktadır.

Ortaya çıkan bu sonuçlar bağlamında pazarlama çalışmalarında Z kuşağı bireyleri hedef pazar olarak belirlemiş marka ve firmalara sunulabilecek öneriler aşağıda sıralanmıştır:

Z kuşağı bireylerin satın alma karar tarzlarının tam olarak şekillendiğini söylemek doğru olmayacaktır. Dolayısı ile bu kitleyi hedef pazar olarak belirleyen marka ve firmaların daha fazla araştırma yapması önerilmektedir.

Z kuşağına ulaşmak için geleneksel pazarlama iletişim araçlarının kullanılmasının yanı sıra ağırlığın sosyal medya, mobil vb. yeni yöntem ve araçlara verilmesi önerilmektedir.

Z kuşağına ulaşabilmek için geleneksel ünlülerden oluşan reklam yüzleri yerine sosyal medya ünlülerinin tercih edilmesi önerilmektedir.

Z kuşağı bireyler için arkadaşlar son derece önemlidir. Dolayısı ile arkadaş grupları içindeki fikir liderleri veya öne çıkan bireyler üzerinden bu kuşak üyeleri ile iletişim kurulması, mümkünse markaların kendi topluluklarını oluşturmaları önerilmektedir.

Z kuşağı bireyler için ürünlerin kalitesi ve fiyatı önceliklidir. Dolayısı ile sunulacak pazarlama karmasında fiyatkalite konusuna dikkat edilmesi önerilmektedir.

Sonuç olarak zaman ilerlemekte, hemen hemen her alanda yepyeni kavramlar, araç ve gereçler hayatımıza girmektedir. Yeni kuşaklar da sahip oldukları kendilerine has özellikler ile kendilerine ayrı yer açmaktadırlar. Marka ve firmaların bir öncekinden hep farklı olacak bu yeni kuşakları daha fazla anlamak için onlarla işbirliği içinde hareket ederek onların önceki nesillerden daha donanımlı olduklarının farkında olarak pazarlama iletişim çalışmalarını kurgulamaları gerekmektedir. Ayrıca marka ve firmaların Z kuşağı tüketicileri homojen bir pazar olarak görmemelerini kendi içlerinde farklılıkların olabileceğini ancak ve bu farklılıkları dikkate almaları durumunda başarılı olabilecekleri yorumu yapılabilecektir. Aksi takdirde kendi alışkanlıkları ile bu yeni kuşaklara geleneksel yollarla ulaşmak istemeleri durumunda başarılı olamayacakları konusunda herkes hemfikirdir.

Yapılan araştırmanın birtakım kısıtları bulunmaktadır. İlk kısıt araştırmanın sadece Kastamonu ilinde yapıllmış olmasıdır. Araştırmada kolayda örneklem yönteminin seçilmesi ise ikinci kısıtı oluşturmaktadır. Bundan sonraki çalışmalarda ise örneklem hacminin arttırılarak ülkemizde ki Z kuşağını temsil edecek, farklı demografik özelliklerini de dikkate alacak çalışmaların yapılması önerilmektedir. Ayrıca Z kuşağı bireylerin, hedonik tüketim alışkanlıkları, mobil alışveriş davranışları, diğer kuşaklar ile aralarındaki farkların ortaya konulmasına yönelik çalışmaların yapılmasının bu kuşak üyelerini anlamada önemli katkılar sağlayacağı düşünülmektedir. 


\section{KAYNAKÇA}

Adıgüzel, O, Batur, H. Ve Ekşili, N. (2014). Kuşakların Değişen Yüzü Ve Y Kuşağı İle Ortaya Çıkan Yeni Çalışma Tarzı: Mobil Yakalılar. Süleyman Demirel Üniversitesi Sosyal Bilimler Enstitüsü Dergisi, 1 (19), 165-182.

Altuntuğ, Nevriye. (2012). Kuşaktan Kuşağa Tüketim Olgusu Ve Geleceğin Tüketici Profili. Organizasyon Ve Yönetim Bilimleri Dergisi 4 (1).

Baldwin, Mark. (2018). 13 Things Marketers Need To Know About Generation Z. https://tukuinc.com/wpcontent/uploads/2018/01/GenZ_TUKU_Jan2018.pdf (Erişim tarihi: 02.05.2019)

Bassiouni, Dina ve Hackley, Chris. (2014). Generation Z Children's Adaptation to Digital Consumer Culture: A Critical Literature Review. Journal of Customer Behaviour, 13/2, 113-133.

Bayrakdaroğlu, Funda ve Özbek, Çağlar. (2018). Kadınların Tüketim Alışkanlıklarının Kuşaklararası Boyutu. Journal of Social Sciences and Humanities Researches 19 (42).

Bilgili, Z. (2016). Tüketici Karar Verme Tarzlarının Kuşaklara Göre Değerlendirilmesi. Elektronik Sosyal Bilimler Dergisi, 15 (59), 1392-1402

Budac, A. C. (2014). Strategic consideration on how brands should deal with generation Z. Journal of Communication Management, 66, 6-14.

Bulut, Zeki Atıl., Çımrin, Kökalan, Füsun ve Doğan, Onur. (2017). Gender, generation and sustainable consumption: Exploring the behaviour of consumers from Izmir, Turkey. International Journal of Consumer Studies, 41, 597604.

Can,Polat ve Yiğit, İlker. (2018). Hedonik Satın Alma Değerlerinin Alışveriş Memnuniyetine Etkisi Üzerine X ve Z Kuşaklarında Karşılaştırmalı Bir Araştırma. İşletme Araştırmaları Dergisi 10 (3), 821-847.

Cruz, Marta. (2016). Generation Z: influencers of decision-making process. Universidade Católica Portuguesa, Católica Porto Business School, Master Thesis.

Çaycı, Berk ve Karagülle, Ayşegül Elif. (2014). X Kuşağından Z Kuşağına Değişen Mahremiyet Algısı. International Trends and Issues in Communication \& Media Conference.

Deniz, E. (2019). Tesettürlü Üniversite Öğrencilerinin Tesettür Giyim Alışverişlerinde Karar Verme Tarzları Üzerine Bir Araştırma. İnsan ve Toplum Bilimleri Araştırmaları Dergisi, 8 (1), 382-407.

Dursun, İnci., Alnıaçık, Ümit ve Kabadayı, Emre Tümer. (2013). Tüketici Karar Verme Tarzları Ölçeği: Yapısı Ve Boyutları. Uluslararası Yönetim İktisat ve İşletme Dergisi, 9 (19).

Duygulu, Serap. (2018). Yeni Medya Teknolojilerinin K-Kuşağının Ebeveynleriyle Olan İletişimine Etkisi. TRT Akademi, 3 (6).

Erciş, Aysel., Ünal, Sevtap ve Can, Polat. (2007). Yaşam Tarzlarının Satın Alma Karar Süreci Üzerindeki Rolü. İktisadi ve İdari Bilimler Dergisi, 21 (2).

Erdem, K. (2016). Tüketicilerin Demografik Özellikleri İle Satın Alma Tarzları Arasındaki İlişki: Aydın İlindeki Tüketiciler Üzerine Bir Araştırma. (Yüksek Lisans Tezi) Adnan Menderes Üniversitesi Sosyal Bilimler Enstitüsü İşletme Anabilim Dalı. Aydın.

Goh, Edmund ve Lee, Cindy. (2018). A workforce to be reckoned with: The emerging pivotal Generation Z hospitality workforce. International Journal of Hospitality Management, 73, 20-28.

Hatipoğlu, Z. (2014). Örgütsel Bağlılık ve İş Tatmini Arasındaki İlişkinin X Ve Y Kuşaklarına Göre Farklılıklarının İncelenmesi. (Doktora Tezi), Arel Üniversitesi Sosyal Bilimler Enstitüsü, Istanbul.

Hızlan, S. K. (2019). E-Ticarette Tüketici Satın Alma Karar Süreci: İnternet Alışverişinde Kasko Ve Trafik Sigortası Karşılaştırma Sitelerinin İncelenmesi. (Yüksek Lisans Tezi). İstanbul Kültür Üniversitesi Lisansüstü Eğitim Enstitüsü. İstanbul.

Hidvégi, Anna ve Kelemen-Erdős, Anikó. (2016). Assessing the Online Purchasing Decisions of Generation Z. FIKUSZ'16 Symposium for Young Researchers.

Işık, Metin ve Kaptangil, İrem. (2018). Akıllı Telefon Bağımlılığının Sosyal Medya Kullanımı ve Beş Faktör Kişilik Özelliği İle İlişkisi: Üniversite Öğrencileri Üzerinden Bir Araştırma. İnsan Ve Toplum Bilimleri Araştırmaları Dergisi, 7 (2).

Kamaruddin, A. ve Mokhlis, S. (2003). Consumer Socialization, social structural factors and decision-making styles:a case study of adolescents in Malaysia. International Journal of Consumer Studies. 27(2),146-156.

Karaman, H. (2015). Açımlayıcı Faktör Analizinde Kullanılan Faktör Çıkartma Yöntemlerinin Karşılaştırılması. Hacettepe Üniversitesi Lisansüstü Eğitim-Öğretim ve Sınav Yönetmeliğinin Eğitim Bilimleri Anabilim Dalı, Ölçme ve Değerlendirme Bilim Dalı. Yayınlanmamış Yüksek Lisans Tezi

Karaca, Şükran. (2013). Tüketicilerin Yeşil Ürünlere İlişkin Tutumlarının İncelenmesine Yönelik Bir Araştırma. Ege Akademik Bakış, 13 (1).

Kavalcı, Kübra ve Ünal, Sevtap. (2016). Y ve Z Kuşaklarının Öğrenme Stilleri ve Tüketici Karar Verme Tarzları Açısından Karşılaştırılması. Atatürk Üniversitesi Sosyal Bilimler Enstitüsü Dergisi, 20 (3), 1033-1050

Kılıç, Hicran Özgüner ve Karadayılı Seçkin. (2017). Z Kuşağının Sosyal Ağ Sitelerinde Yer Alan Markaların Pazarlama Uygulamalarına Yönelik Algısı: Karabük İli Üzerine Bir Araştırma. Route Educational and Social Science Journal, 4 (8).

Kitchen, P. J., ve Proctor, T. (2015). Marketing communications in a postmodern world. Journal of Business Strategy, 36 (5), 34-42. 
Kotler, P. (2000). Pazarlama Yönetimi, Millennium Baskı, Çev. Nejat Muallimoğlu, Beta, İstanbul.

Kuran, E. (2018). Telgraftan Tablete Türkiye'nin Beş Kuşağına Bakış, Destek Yayınları, İstanbul

Lastovicka, J. L. (1982). On the Validation of Lifestyle Traits: A Review and Illustration. Journal of Marketing Research, 19 (1), 126-138.

Léa, Claude., Malek, Paulina ve Runnvall, Lisa. (2018). Influencers impact on decision-making among generation Y and Z Swedish females when purchasing fast fashion. Jönköping University Business School Bachelor Thesis.

Leo, C., Bennett, R., ve Charmine E.J. (2005). Cross-cultural differences in consumer decision-making styles. CrossCult.Manag, 12 (3), 31.

Levickaité, Rasa. (2010). Generations X, Y, Z: How Social Networks Form the Concept of the World Without Borders (The Case of Lithuania), LIMES, 3 (2), 170-183.

Onurlubaş, E. ve Altunışık, R. (2019). Tüketici Etnosentrizmi ve Marka İmajının Satın Alma Niyeti Üzerindeki Etkisi: Gıda Tüketicileri Üzerine Bir Uygulama, Uluslararası Toplum Araştırmaları Dergisi, 10 (17), 277-307.

Özden, Aybike Tuba. (2019). Pozitif Algının ve Tüketici Karar Verme Tarzlarının Y ve Z Kuşakları Açısından Karşılaştırılması. Gazi İktisat ve İşletme Dergisi, 5(1), 1-20.

Perlstein, J. (2017). Engaging Generation Z: Marketing to a New Brand of Consumer. [online] Adweek.com. Available at: https://www.adweek.com/digital/josh-perlstein-response-media-guest-post-generation-z/ [Accessed 17 Nov. 2018].

Sarı, Emre ve Harta, Gözde. (2018). Kuşakların Tüketim Ve Satın Alma Davranışları Üzerine Bir Araştırma. Uluslararası Sosyal Araştırmalar Dergisi, 11 (61).

Sarığlu, Elif Başak ve Özgen, Ebru. (2017). Z Kuşağı: İş Dünyası Yakın Geleceğin İş Gücünü Ne Kadar Tanıyor? Researcher: Social Science Studies, 5 (IV), 242-253.

Sarığlu, Elif Başak ve Özgen, Ebru. (2018). Z Kuşağının Sosyal Medya Kullanım Alışkanlıkları Üzerine Bir Çalışma. Uluslararası Sosyal Araştırmalar Dergisi, 11 (60).

Scott, S. G., ve Bruce, R. A. (1995). Decision-making style: The development and assessment of a new measure. Educational and Psychological Measurement, 55 (5), 818-831.

Seckin, Sedef. (2000). Turkiye'nin Kusak Profili. Capital Degisi, 12.

Silva, Susana Costa, Machado, Joana César ve Cruz, Marta. (2017). The influence of WOM and Peer Interaction in the Decision-Making Process of Generation $\mathrm{Z}$ within the family. International Journal of Marketing, Communication. Special Number $2 \mathrm{Mdb}$, October.

Smalej, Olga. (2017). Analysıs Of Purchasıng Decısıons Made By The Generation Z Consumers. Management, Knowledge and Learning International Conference 17-19 May Lublin / Poland 2017

Sproles, G. B. (1985). From Perfectionism to Fadism: Measuring Consumers' DecisionMaking Styles. Proceedings, American Council On Consumer Interests. 79-85.

Sproles, G.B. ve Kendall, E.L. (1986). A Methodology for Profiling Consumer Decision-Making Styles, Th e Journal of Consumer Affairs, 20 (2), 267-279.

Tabachnick, B.G. \& Fidell, L.S. (2013). Using Multivariate Statistics. Pearson, Boston

Tanksale, D., Neelam, N. ve Venkatachalam, R. (2014). Consumer decision making styles of young adult consumers in India. Procedia - Social and Behavioral Sciences, 133, 211-218.

Taş, H. Yunus., Demirdöğmez, Mehmet ve Küçükoğlu, Mahmut. (2017). Geleceğimiz Olan Z Kuşağının Çalışma Hayatına Muhtemel Etkileri. Uluslararası Toplum Araştırmaları Dergisi, 7(13).

Tekvar, S. O. (2016). Tüketici Davranışlarının Demografik Özelliklere Göre Tanımlanması. İnsan Ve Toplum Bilimleri Araştırmaları Dergisi, 5 (6), 1601-1616.

Torlak, Ömer. (2016) Tüketim Bireysel Eylemin ve Toplumsal Dönüşümü. İnkilap Yayınları:İstanbul

Williams S (2010). Welcome to generation Z. B\&T Magazine, 60(2731): 12-12.

Wood, Stacy. (2013). Generation Z as consumers: trends and innovation. Institute for Emerging Issues. North Carolina State University. 1-3. https://iei.ncsu.edu/wp-content/uploads/2013/01/GenZConsumers.pdf (Erişim tarihi: 10.05.2019)

Yeniçeri, Tülay ve Özal, Halit. (2016). Tüketici Karar Verme Tarzlarının Cinsiyet Kimliğine Göre İncelenmesi. Pazarlama ve Pazarlama araştırmaları Dergisi, 18, 135-168.

Yücel, E. K. (2017). Demografik Özelliklerin Satın Alma Karar Tarzları Üzerine Etkisi: Beyaz Eşya Ürünleri Üzerine Bir Uygulama. AKÜ İktisadi ve İdari Bilimler Fakültesi Dergisi, 19 (2), 53-68

TÜİK. (2019). http://tuik.gov.tr/UstMenu.do?metod=temelist (Erişim tarihi: 21.05.2019)Pollan, Michael. 2006. The Omnivore's Dilemma: A Natural History of Four Meals. New York: Penguin. 